\title{
Spatial Integration of Biological and Social-Objectives to Identify Priority Landscapes for Waterfowl Habitat Conservation
}

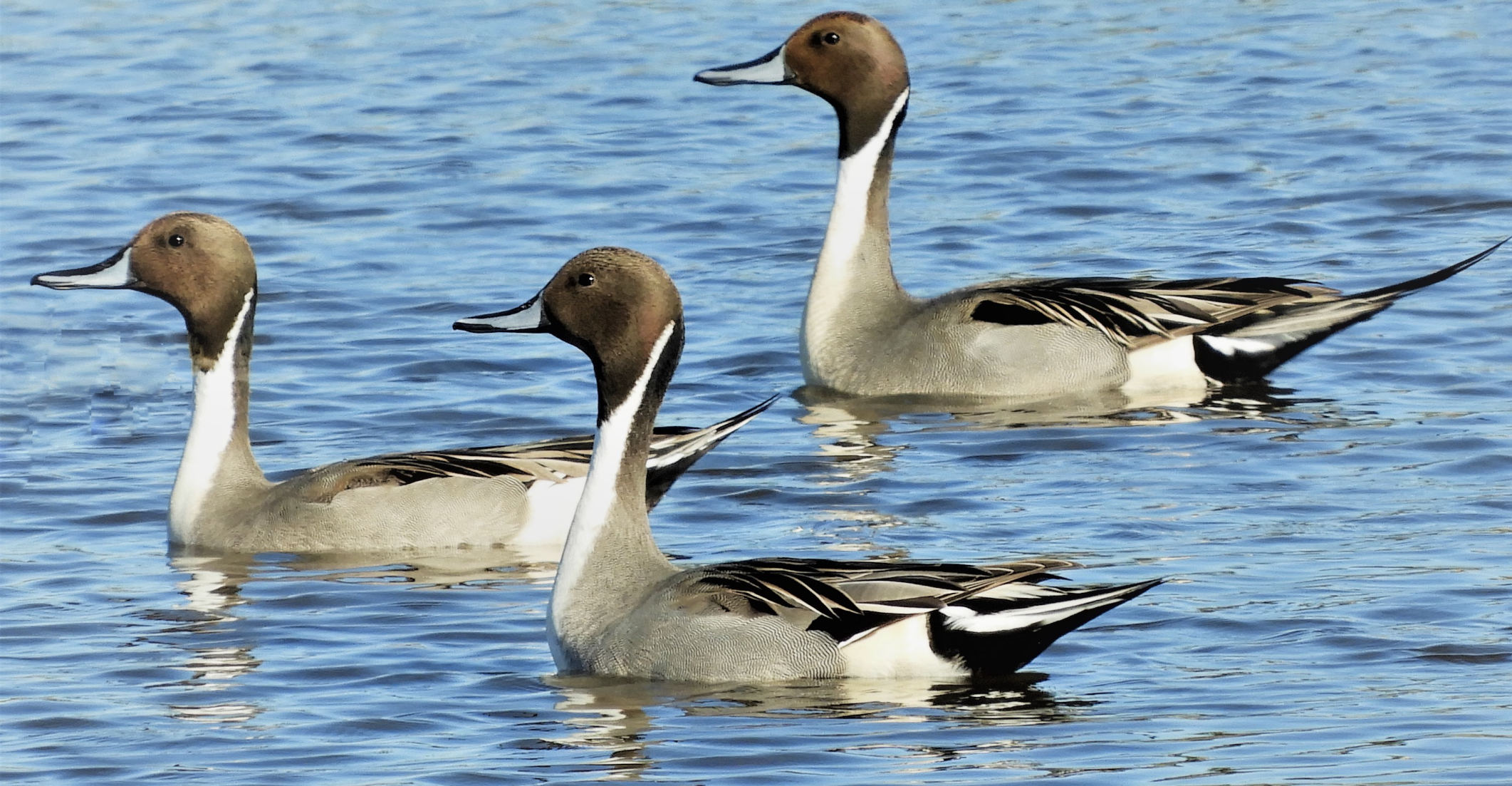

Open-File-Report $2019=1029$ 
Cover. Photograph of three northern pintails on the water, South Padre Island, Texas. Photograph by Ross Owen Couvillon, PhD., Professor at Wharton County Junior College. 


\section{Spatial Integration of Biological and Social Objectives to Identify Priority Landscapes for Waterfowl Habitat Conservation}

By Anastasia Krainyk, James E. Lyons, Michael G. Brasher, Dale D. Humburg, Gregory J. Soulliere, John M. Coluccy, Mark J. Petrie, David W. Howerter, Stuart M. Slattery, Mindy B. Rice, and Joe C. Fuller

Open-File Report 2019-1029 


\title{
U.S. Department of the Interior \\ DAVID BERNHARDT, Secretary
}

\author{
U.S. Geological Survey \\ James F. Reilly II, Director
}

U.S. Geological Survey, Reston, Virginia: 2019

For more information on the USGS - the Federal source for science about the Earth, its natural and living resources, natural hazards, and the environment-visit https://www.usgs.gov or call 1-888-ASK-USGS.

For an overview of USGS information products, including maps, imagery, and publications,

visit https://store.usgs.gov.

Any use of trade, firm, or product names is for descriptive purposes only and does not imply endorsement by the U.S. Government.

Although this information product, for the most part, is in the public domain, it also may contain copyrighted materials as noted in the text. Permission to reproduce copyrighted items must be secured from the copyright owner.

Suggested citation:

Krainyk, A., Lyons, J.E., Brasher, M.G., Humburg, D.D., Soulliere, G.J., Coluccy, J.M., Petrie, M.J., Howerter, D.W., Slattery, S.M., Rice, M.B., and Fuller, J.C., 2019, Spatial integration of biological and social objectives to identify priority landscapes for waterfowl habitat conservation: U.S. Geological Survey Open-File Report 2019-1029, 41 p., https://doi.org/10.3133/ofr20191029.

ISSN 2331-1258 (online) 


\section{Acknowledgments}

The work described herein would not have been possible without the assistance and commitment of biologists, ecologists, researchers, waterfowl experts, and dozens of sources of waterfowl data, survey teams, and analysts. The authors thank the Priority Landscapes Committee for their dedication to regular meetings, discussions, and edits of multiple interim progress documents. We also thank M. Al-Saffar of U.S. Fish and Wildlife Service for spatial-analysis consultation, and we thank the reviewers, Robert Clark of Environment and Climate Change Canada and Mark Parr of U.S. Fish and Wildlife Service, whose generous commitment of time resulted in a greatly improved report. The completion of this work would not be possible without the financial assistance of the U.S. Fish and Wildlife Service. Findings and conclusions of this report are those of the authors and do not necessarily represent the views of U.S. Fish and Wildlife Service. 



\section{Contents}

Abstract

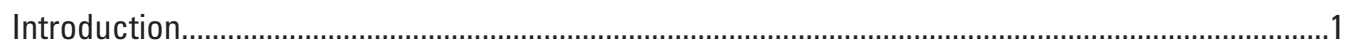

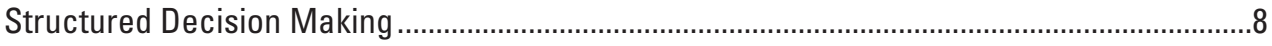

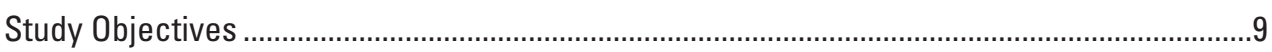

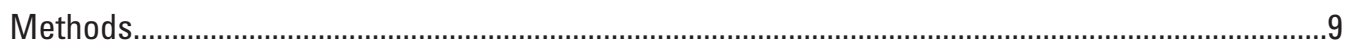

Establishing Essential Framework and the Priority Landscapes Committee.............................9

Identifying the Problem Statement ...................................................................................

Identifying Objectives and Developing Objectives Hierarchies ..............................................10

Selecting Performance Measures and Data Sources ..........................................................12

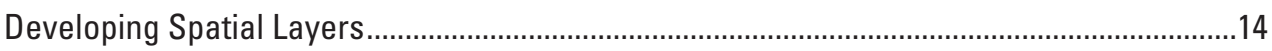

Developing Utility Functions and Standardization of Spatial Layers .......................................16

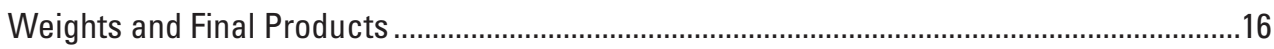

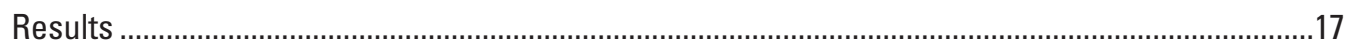

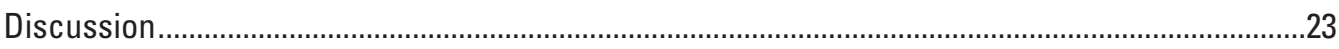

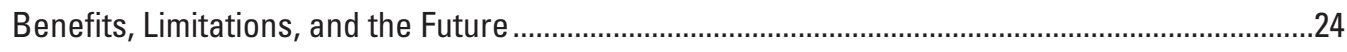

Summary

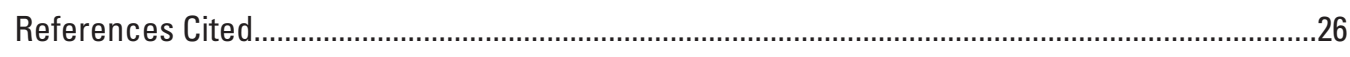

Appendix 1. Members of the Priority Landscapes Committee ......................................................32

Appendix 2. Purpose and Function of Priority Landscapes Committee.........................................33

Appendix 3. Means-Ends Network Diagram of Waterfowl Habitat Conservation Decision Context..............................................................................................................

Appendix 4. Biological Objectives: Duck Species Objectives Hierarchy ......................................37

Appendix 5. Biological Objectives: Goose and Swan Species Objectives Hierarchy...................39

Appendix 6. Social Objectives Hierarchy …………..............................................................40 


\section{Figures}

1. Map showing the historical evolution of spatially explicit products to target conservation of waterfowl habitat: $A$, waterfowl habitat areas of major concern in the United States and Canada, $B$, important waterfowl habitat areas, $C$, important waterfowl habitat areas in North America, and $D$, areas of continental significance to North American ducks, geese, and swans.

2. Map showing areas of greatest continental significance to North American ducks, geese, and swans

3. Map showing relative importance of geographies to waterfowl during the breeding and non-breeding periods

4. Map showing relative importance of geographies to waterfowl during the breeding period

5. Map showing relative importance of geographies to waterfowl during the non-breeding period

6. Map showing relative importance of geographies to waterfowl conservation supporters

7. Map showing relative importance of geographies to waterfowl during the breeding and non-breeding periods and to waterfowl habitat conservation supporters

\section{Conversion Factors}

U.S. customary units to International System of Units

\begin{tabular}{|c|c|c|}
\hline Multiply & By & To obtain \\
\hline \multicolumn{3}{|c|}{ Length } \\
\hline mile (mi) & 1.609 & kilometer (km) \\
\hline mile, nautical (nmi) & 1.852 & kilometer (km) \\
\hline yard (yd) & 0.914 & meter $(\mathrm{m})$ \\
\hline \multicolumn{3}{|c|}{ Area } \\
\hline acre & 4,047 & square meter $\left(\mathrm{m}^{2}\right)$ \\
\hline acre & 0.4047 & hectare (ha) \\
\hline acre & 0.4047 & square hectometer $\left(\mathrm{hm}^{2}\right)$ \\
\hline acre & 0.004047 & square kilometer $\left(\mathrm{km}^{2}\right)$ \\
\hline $\begin{array}{l}\text { section ( } 640 \text { acres or } \\
1 \text { square mile) }\end{array}$ & 259.0 & square hectometer $\left(\mathrm{hm}^{2}\right)$ \\
\hline square mile $\left(\mathrm{mi}^{2}\right)$ & 259.0 & hectare (ha) \\
\hline square mile $\left(\mathrm{mi}^{2}\right)$ & 2.590 & square kilometer $\left(\mathrm{km}^{2}\right)$ \\
\hline \multicolumn{3}{|c|}{ Application rate } \\
\hline $\begin{array}{l}\text { pound per acre per year } \\
([\mathrm{lb} / \mathrm{acre}] / \mathrm{yr})\end{array}$ & 1.121 & $\begin{array}{l}\text { kilogram per hectare per year } \\
([\mathrm{kg} / \mathrm{ha}] / \mathrm{yr})\end{array}$ \\
\hline
\end{tabular}


Temperature in degrees Celsius $\left({ }^{\circ} \mathrm{C}\right)$ may be converted to degrees Fahrenheit $\left({ }^{\circ} \mathrm{F}\right)$ as follows:

$$
{ }^{\circ} \mathrm{F}=\left(1.8 \times{ }^{\circ} \mathrm{C}\right)+32 .
$$

Temperature in degrees Fahrenheit $\left({ }^{\circ} \mathrm{F}\right)$ may be converted to degrees Celsius $\left({ }^{\circ} \mathrm{C}\right)$ as follows:

$$
{ }^{\circ} \mathrm{C}=\left({ }^{\circ} \mathrm{F}-32\right) / 1.8 \text {. }
$$

\section{Datum}

Horizontal coordinate information is referenced to the Projected: North American Albers Equal Area Conic and Geographic: GCS North American 1983.

\section{Abbreviations}

$\begin{array}{ll}\text { BCR } & \text { Bird Conservation Region } \\ \text { CWS } & \text { Canadian Wildlife Service } \\ \text { DOI } & \text { U.S. Department of the Interior } \\ \text { DUD } & \text { Duck use days } \\ \text { HDA } & \text { Hunter days afield } \\ \text { HDWG } & \text { Human Dimensions Working Group } \\ \text { IIC } & \text { Interim Integration Committee } \\ \text { JV } & \text { Joint Venture } \\ \text { MAUT } & \text { Multi-Attribute Utility Theory } \\ \text { NAWMP } & \text { North American Waterfowl Management Plan } \\ \text { NSST } & \text { NAWMP Science Support Team } \\ \text { PLC } & \text { Priority Landscapes Committee } \\ \text { SDM } & \text { Structured decision making } \\ \text { USFWS } & \text { U.S. Fish and Wildlife Service } \\ \text { USGS } & \text { U.S. Geological Survey }\end{array}$





\title{
Spatial Integration of Biological and Social Objectives to Identify Priority Landscapes for Waterfowl Habitat Conservation
}

\author{
By Anastasia Krainyk', James E. Lyons' ${ }^{1}$, Michael G. Brasher², Dale D. Humburg², Gregory J. Soulliere ${ }^{3}$, \\ John M. Coluccy², Mark J. Petrie ${ }^{2}$, David W. Howerter², Stuart M. Slattery², Mindy B. Rice ${ }^{3}$, and Joe C. Fuller
}

\section{Abstract}

Waterfowl population management and habitat conservation compose one of the oldest and most successful adaptive management frameworks in the world. Since its inception, the North American Waterfowl Management Plan (NAWMP) has emphasized strategically targeted conservation investments in regions that most affect waterfowl population dynamics. By 2012, regional conservation had progressively become more science-based and strategic: many migratory bird partnerships had initiated or completed projects on mapping and modeling waterfowl distribution and abundances using geospatial techniques. However, when developing a map depicting and titled "Areas of Greatest Continental Significance to North American Ducks, Geese, and Swans" for the 2012 NAWMP Revision, waterfowl professionals articulated the need for improved decision frameworks and use of consistent datasets for refining large-scale spatial products depicting priority areas for waterfowl and people. This report describes a framework for developing a spatial value model to support the identification of North American geographies of importance to waterfowl during the breeding and non-breeding periods and to resource users who could potentially support (financially and (or) politically) waterfowl habitat conservation. Objectives used to identify priority geographies were determined through a collaborative process of the NAWMP Science Support Team, Priority Landscapes Committee (PLC), and other experts in the fields of waterfowl biology and ecology, environmental science, and human dimensions. ArcGIS Desktop was used as the platform for managing, analyzing, combining and displaying the spatial data as well as producing new data through spatial analysis functions. Thirty-eight spatial layers were developed, and several composite spatially

\footnotetext{
${ }^{1}$ U.S. Geological Survey.

${ }^{2}$ Ducks Unlimited.

${ }^{3}$ U.S. Fish and Wildlife Service.

${ }^{4}$ North Carolina Resource Commission.
}

explicit products (maps of North America) were produced based on PLC recommendations. The composite products have extensive similarities to the 2012 NAWMP map depicting areas of greatest continental significance to North American waterfowl. There are also some differences, especially in regions of the high Arctic and in Mexico. These differences between spatial value model maps and the 2012 NAWMP output likely arose from inclusion of social objectives, reduced dependence on expert opinion to generate abundance estimates, lack of population surveys in some regions and availability of expanded survey data in other regions, and use of model-based waterfowl population estimates for some unsurveyed areas.

The structured decision-making framework application in this study is discussed, and the appropriate use of the products and their limitations are outlined. Additionally, options for future improvements are presented by identifying gaps in data collection, waterfowl-habitat association assumptions, and uncertainties related to social objectives. These spatial products are intended for use by national, regional, and province/state level wildlife professionals to aid their decisions in targeting waterfowl habitat conservation.

\section{Introduction}

Waterfowl habitat conservation and population management in North America exemplify the oldest and most successful adaptive management frameworks in the world (Williams and others, 1999; Anderson and Padding, 2015). Since the 1950s, biologists, ecologists, and hunters have worked in partnership to conserve and manage waterfowl breeding and non-breeding habitat to support continental waterfowl populations and the tradition of waterfowl hunting. This partnership of government and non-government organizations and private entities became more formalized with development of the first North American Waterfowl Management Plan (NAWMP, 1986) Although the NAWMP is continental in scope, regional Joint Venture (JV) partnerships were established to implement this international plan; JV partners shared 
knowledge and resources to increase efficiencies in habitat conservation delivery at local scales. Since its inception, the NAWMP has emphasized strategically targeted conservation investments in regions that likely will have the greatest positive effect on waterfowl population dynamics.

Spatial products released in the 1986 NAWMP and subsequent revisions identify the regional and sub-regional geographies considered most important for waterfowl production and survival. The first NAWMP (1986) included a map titled "Waterfowl Habitat Areas of Major Concern in the United States and Canada," and subsequent updates included iterations of important waterfowl habitat areas (NAWMP, 1994, 1998; fig.1) or areas of continental significance to waterfowl populations (NAWMP, 2004; fig. 1). The development of these spatial products was largely based on waterfowl population survey data, expert knowledge, and various research efforts. Expansion of areas identified as important to waterfowl in the maps from NAWMP $(1994,1998)$ coincided with an increase in the number of JVs in North America. However, more advanced geospatial tools soon became available, leading to better mapping of biologically important areas and identification of priority geographies, based on biological and ecological data. Additionally, NAWMP (1986, 1994, 1998, and 2004) had not explicitly included objectives for identifying priority landscapes for resource allocation that would benefit consumptive and non-consumptive waterfowl habitat resource users.

By 2012, many JVs had initiated or completed projects on mapping and modeling waterfowl distributions and abundances using geospatial techniques, and regional conservation continued to become more science based and strategic (Reynolds and others, 2006; Soulliere and Al-Saffar, 2017; Soulliere and others, 2017). Additionally, the benefits of waterfowl habitat conservation to people had become more readily, if not explicitly, considered in resource allocation decisions. Soulliere and others (2012) reviewed the process they used to develop a map "Areas of Greatest Continental Significance to North American Ducks, Geese, and Swans" for the 2012 NAWMP Revision (fig. 2) and outlined several deficiencies, including lack of consistent decision criteria for assessing significance, variable quality, and reliability of data among JVs, and the exclusion of social objectives. Ultimately, they concluded that articulation of key decision frameworks, explicit objectives, consistent datasets, and the inclusion of social objectives were needed to develop a more meaningful decision support system and conservation planning tools at the continental scale (Soulliere and others, 2012).

The 2012 NAWMP included social components in each of its three fundamental goals - (1) maintain abundant and resilient waterfowl populations to support hunting and other uses without impairing habitat; (2) maintain wetlands and related habitats sufficient to sustain waterfowl populations at desired levels, while providing places to recreate and ecological goods and services that benefit society; and (3) encourage an increase in the numbers of waterfowl hunters, other conservationists, and citizens who enjoy and actively support waterfowl and wetland conservation. For the first time, the plan advocated for integration of biological objectives with social objectives. The importance of identifying landscapes that are critical to waterfowl during the annual cycle can no longer be considered in isolation from landscapes that people depend on and value. The increasing effect of human activities on biodiversity is projected to have broad ramifications on society (Sala and others, 2000), but the spatial extent of these ramifications is unlikely to be evenly distributed (Imhoff and others, 2004; Evans and others, 2006). The application of geographically explicit conservation tools (that is, the spatial value model, as defined herein) has the potential to aid decision makers in developing conservation strategies that promote multi-use resource management while mitigating the effects of human activities on biodiversity and garnering support for conservation (Millspaugh and Thompson, 2011). Recognizing pending losses in wetland conservation support owing to declining numbers of waterfowl hunters and a North American public increasingly disconnected from nature, the 2012 NAWMP Revision included a key recommendation to "Focus resources on important landscapes that have the greatest influence on waterfowl populations and those who hunt and view waterfowl" (NAWMP, 2012). In this regard, specific steps were identified in the 2012 NAWMP Action Plan (U.S. Department of the Interior and others, 2012), including the following three steps.

- Identify primary issues that must be considered when targeting waterfowl habitat conservation while achieving the three fundamental NAWMP goals.

- Develop scalable decision-support tools for targeting management actions that are based on prioritization of conservation issues, as determined by stakeholder values.

- Identify the most important areas for waterfowl habitat conservation at multiple spatial scales (for example, continental, flyway, JV region).

To advance these recommended steps, resource allocation decisions need to be approached from a multi-use perspective. However, resource allocation decisions with multiple objectives and various spatial scales can become enormously complex in our socioecologically dynamic world (Folke and others, 2005). Given this complexity, there is increasing attention to linking knowledge and action (for example, Sunderland and others, 2009; Walsh and others, 2015). Decision analysis frameworks have emerged as an established means to address the need for structured support of conservation decisions (for example, Margules and Pressey, 2000; Pullin and Knight, 2001; Martin and others, 2009; Cook and others, 2014).

Conservation frameworks provide overarching guidance for planning and decision support in addition to specific tools to accomplish conservation planning. In this report, we address the need for a structured decision framework in North America to identify geographies where habitat conservation can provide the greatest benefits to waterfowl and people. 
A

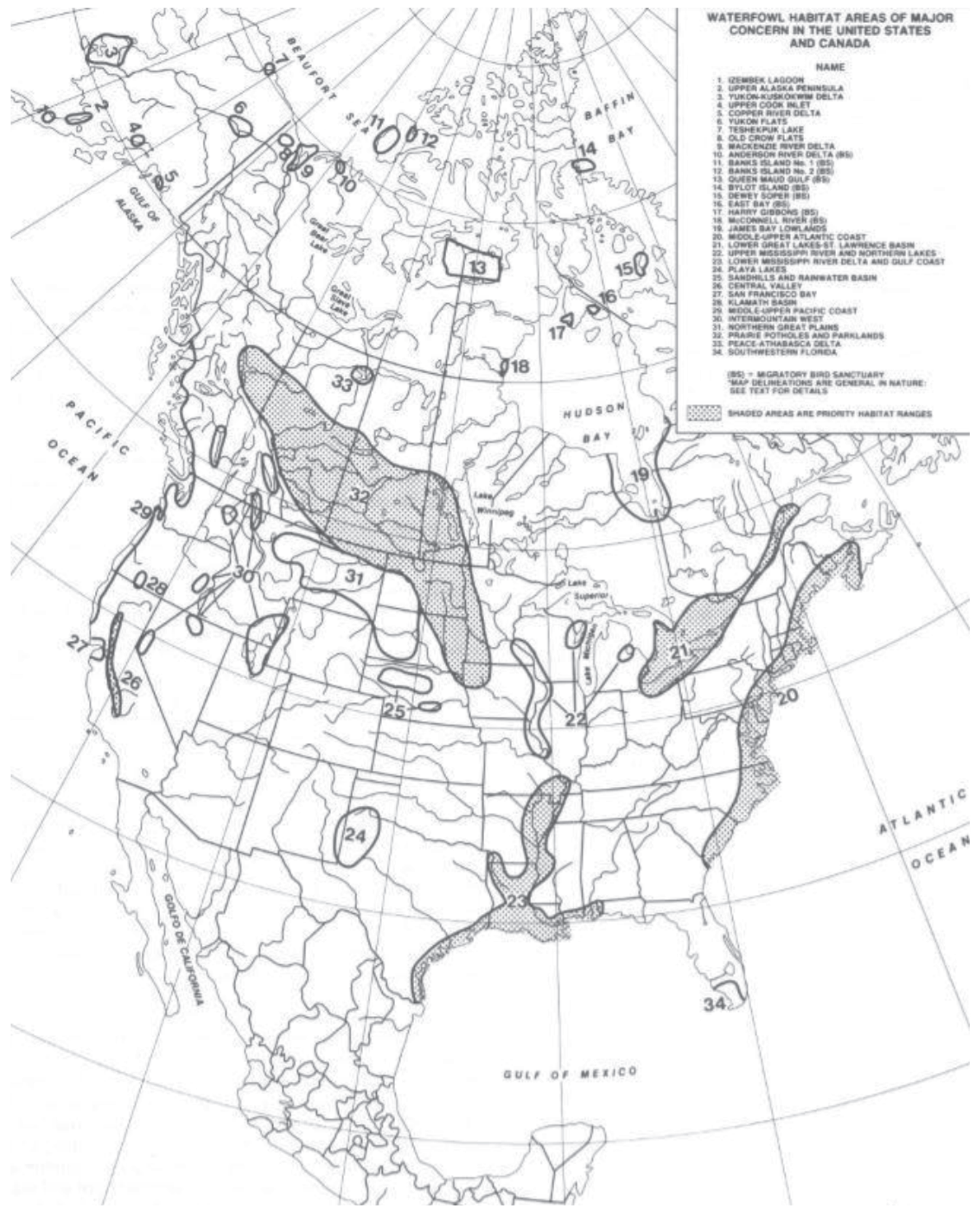

Figure 1. The historical evolution of spatially explicit products to target conservation of waterfowl habitat: $A$, waterfowl habitat areas of major concern in the United States and Canada (from North American Waterfowl Management Plan [NAWMP] 1986), $B$, important waterfowl habitat areas (from NAWMP, 1994), C, important waterfowl habitat areas in North America (from NAWMP, 1998), and D, areas of continental significance to North American ducks, geese, and swans (from NAWMP, 2004). 
$\boldsymbol{B}$

\begin{tabular}{|c|c|c|c|c|c|}
\hline \multicolumn{6}{|c|}{ Map delineations are general in aature } \\
\hline 1 & laenbek Laenon & 14 & Bylost lined (BS) & 24 & Nona tabes of \\
\hline 2 & Cpper Alaska Prainsula & 15 & Bewey Soper (As) & 254 & Rainvat Alasie $\mathrm{F}$ \\
\hline 3 & Yulon-Kushokwin Deles & 16 & East Bay (BS) & 250 & Sondills \\
\hline 4 & tpper Cook Inles & 17 & Harn Gibboes (ES) & 236 & Caitral villey Hatieat $\mathrm{N}$ \\
\hline 5 & Copper Rover Delu & 18 & Moboened fiser (BS) & $n$ & Sua Francives Bay \\
\hline 6 & Yulon Flas & 19 & funes llay Leatands & 28 & Nimath Mavin \\
\hline 7 & Teshekpuek Lake & 300 & Nifunic Cous JV & 29 & Pacilic Coust IN \\
\hline 8 & Old Crow Flats & $20 \mathrm{~b}$ & Eastern Hahitut $N$ & 50 & 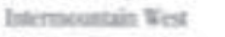 \\
\hline 9 & Mackenze River Dela & 21 & Lewact Great lakes- & 31 & Nonthern Great Flais \\
\hline 10 & Andersom River Dela (BS) & & S. Lavrence Busin Jv & $43 \mathrm{a}$ & Frine llabieat $/ \mathrm{N}$ \\
\hline II & flanks bland No I (Es) & 32 & Lyper Minsodippi iner- & -33 & Mairie Rebie of \\
\hline 12 & Himls Bland No.2 (ES) & 234 & 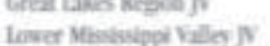 & 33 & Peacr Mluatusca Deta \\
\hline 13 & Queen Musd Gulf (ES) & $-25 b$ & Galf coust in & 34 & 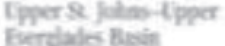 \\
\hline
\end{tabular}
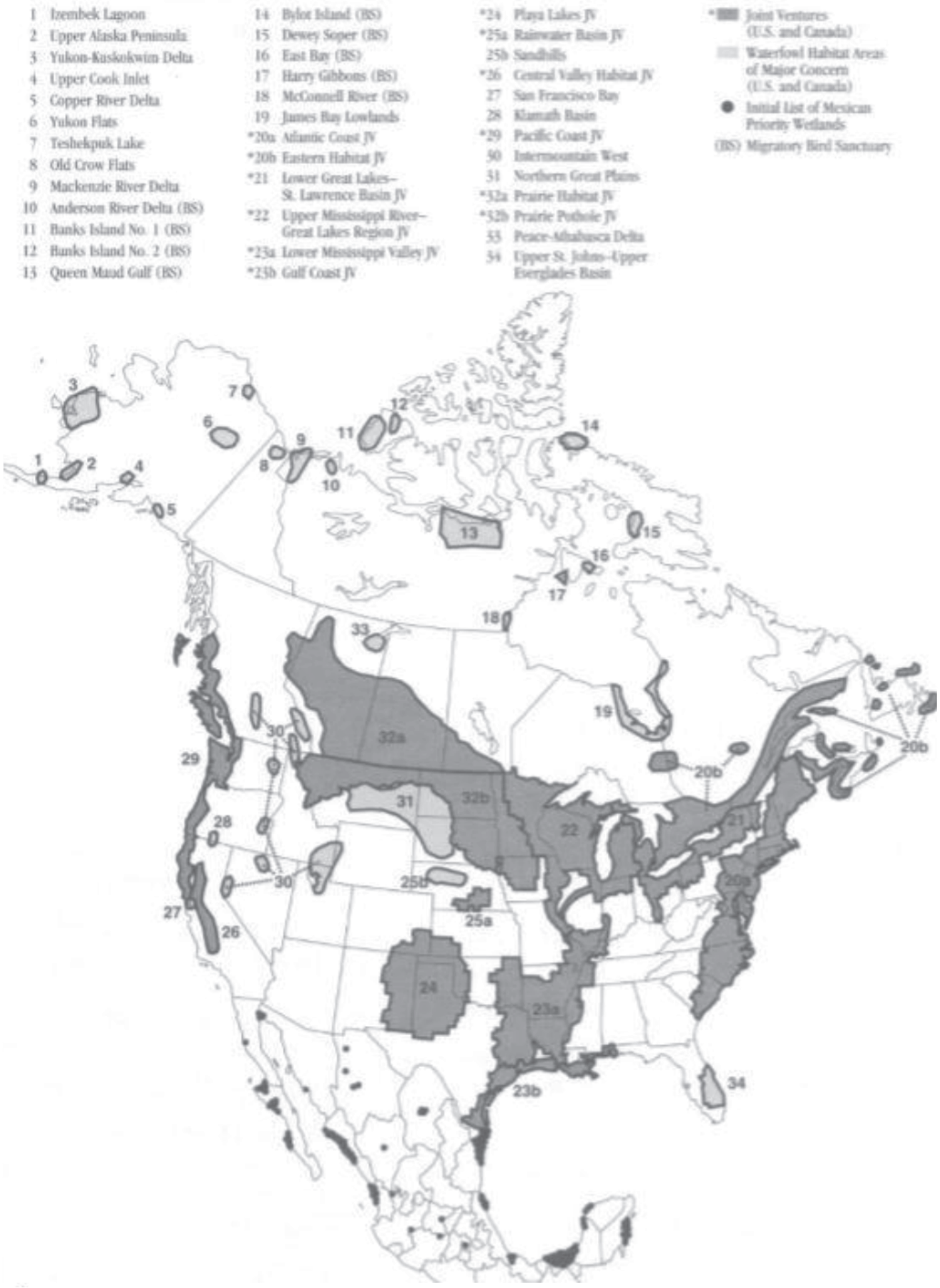

Figure 1. The historical evolution of spatially explicit products to target conservation of waterfowl habitat: $A$, waterfowl habitat areas of major concern in the United States and Canada (from North American Waterfowl Management Plan [NAWMP] 1986), $B$, important waterfowl habitat areas (from NAWMP, 1994), $C$, important waterfowl habitat areas in North America (from NAWMP, 1998), and $D$, areas of continental significance to North American ducks, geese, and swans (from NAWMP, 2004).-Continued 


\section{C \\ Areas of major concern with an active Habitat Joint Venture \\ Areas of major concern without an active Habitat Joint Venture \\ Priority wetland areas of Mexico}

(MBS) Migratory Bird Sanctuary

(JV) Habitat Joint Venture

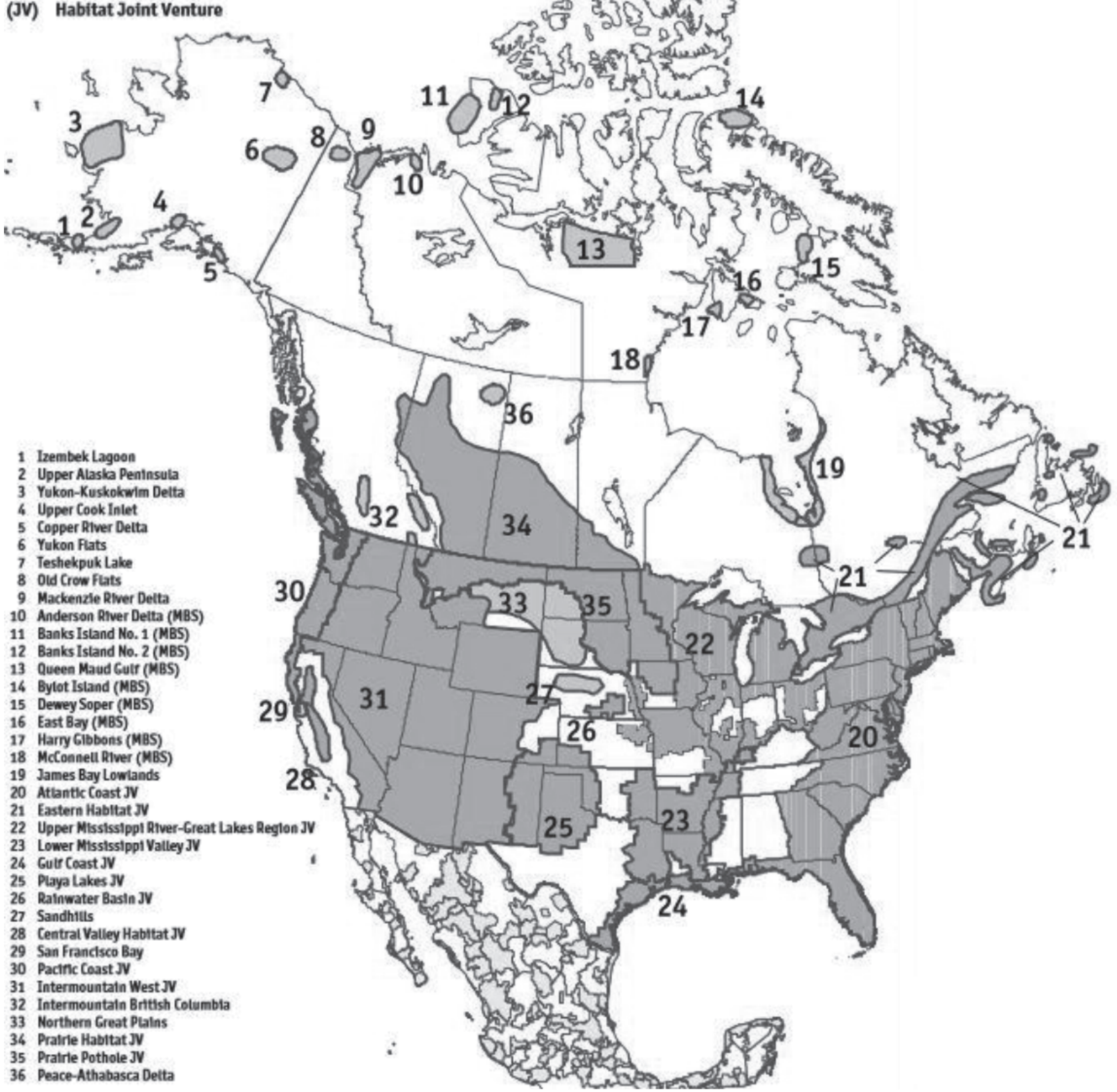

Figure 1. The historical evolution of spatially explicit products to target conservation of waterfowl habitat: $A$, waterfowl habitat areas of major concern in the United States and Canada (from North American Waterfowl Management Plan [NAWMP] 1986), $B$, important waterfowl habitat areas (from NAWMP, 1994), $C$, important waterfowl habitat areas in North America (from NAWMP, 1998), and $D$, areas of continental significance to North American ducks, geese, and swans (from NAWMP, 2004).-Continued 
D

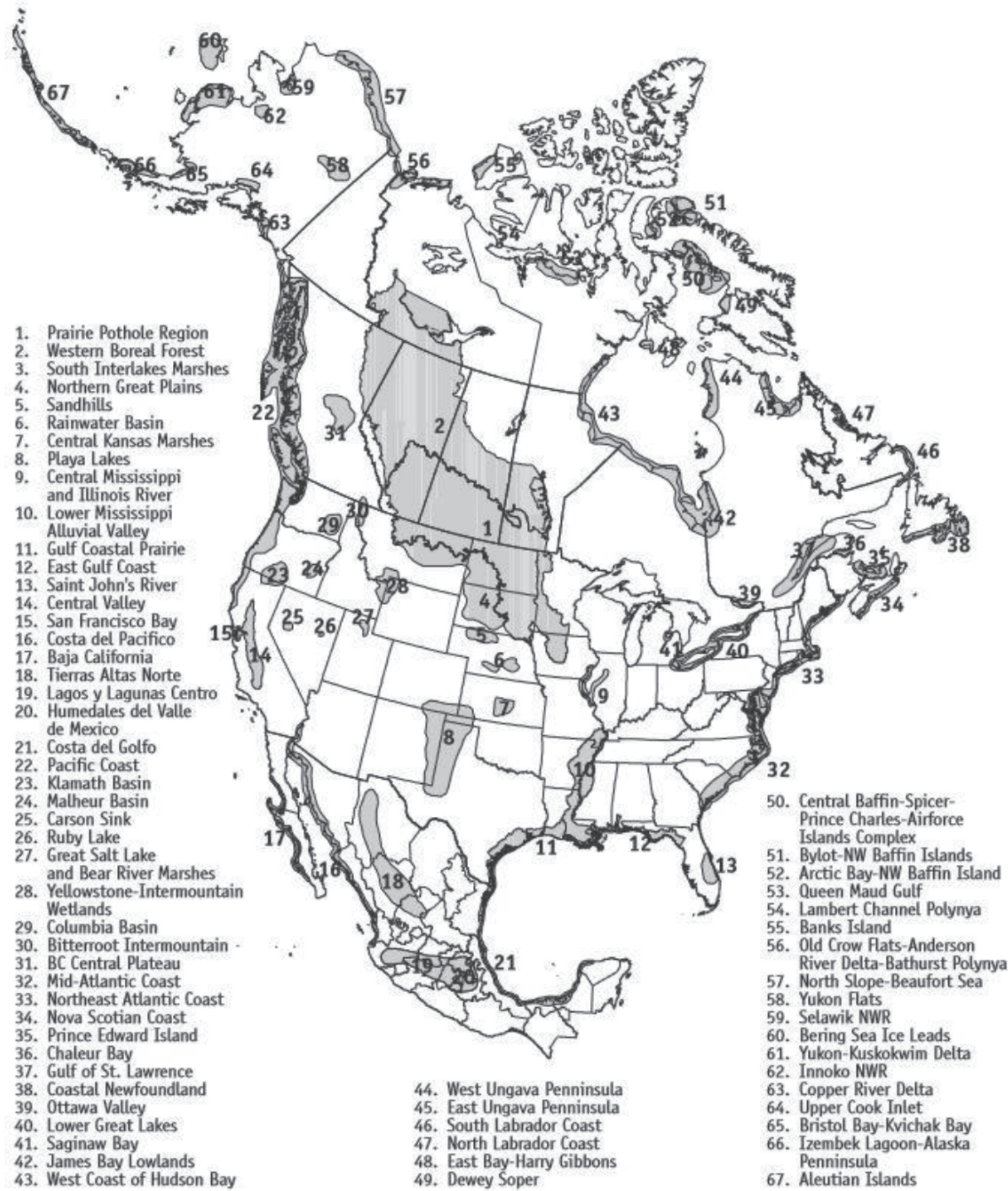

Figure 1. The historical evolution of spatially explicit products to target conservation of waterfowl habitat: $A$, waterfowl habitat areas of major concern in the United States and Canada (from North American Waterfowl Management Plan [NAWMP] 1986), $B$, important waterfowl habitat areas (from NAWMP, 1994), $C$, important waterfowl habitat areas in North America (from NAWMP, 1998), and $D$, areas of continental significance to North American ducks, geese, and swans (from NAWMP, 2004).-Continued 


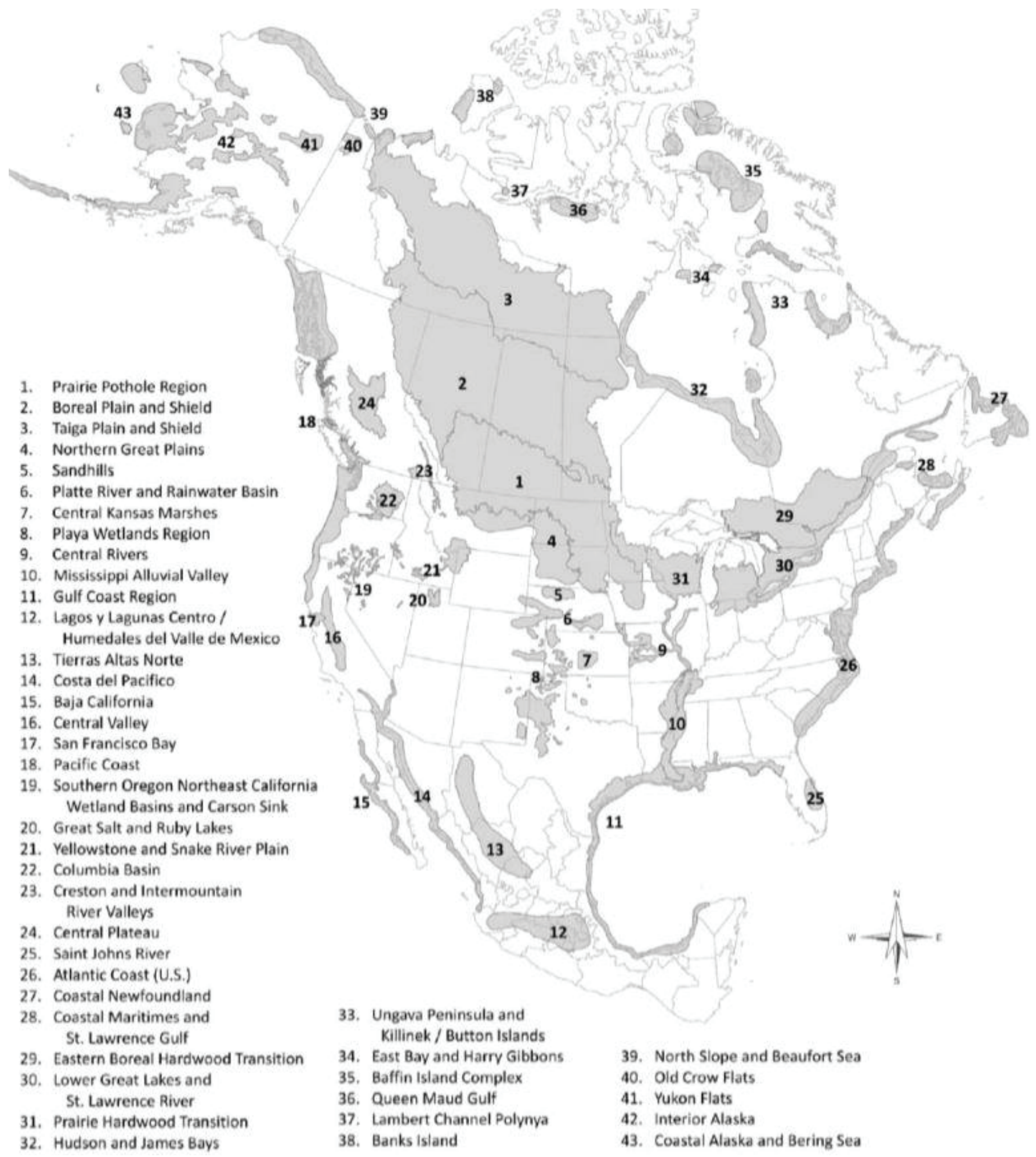

Figure 2. Areas of greatest continental significance to North American ducks, geese, and swans. From Soulliere and others, 2012; NAWMP, 2012. 


\section{Structured Decision Making}

Structured decision making (SDM) is an organized, inclusive, and transparent approach to understanding complex problems and achieving fundamental objectives (Gregory and others, 2012). SDM is a type of decision analysis that emphasizes a collaborative approach to defining the problem, identifying objectives, creating alternatives, predicting consequences of alternatives, and making trade-offs to determine the most appropriate decision(s). PrOACT (Problem, Objectives, Alternatives, Consequences, and Trade-offs) is the commonly used acronym that describes the framework to structure decisions. We used the problem framing approach, where elements such as decision maker, potential actions, ultimate goals to be achieved, temporal and spatial extent of the problem, and the likely constraints are identified independently and then assembled in a problem statement according to a statement formula (Gregory and others, 2012; Romito and others, 2015). Objectives are concise statements of "what matters" (Gregory and others, 2012). These statements of the fundamental interests that may be affected by decisions are context specific and often based on competing interests of various stakeholder groups. Objectives are classified into four categories: fundamental, means, process, and strategic (Von Winterfeldt and Edwards, 2007; Gregory and others, 2012). Performance measures (also called measurable attributes) are specific metrics that can be used to consistently estimate and report the anticipated consequences of a management alternative with respect to an objective (Gregory and others, 2012). Performance measures must be comprehensive and measurable (Keeney and Gregory, 2005). There are three types of performance measures - (1) natural, those that directly describe outcomes that matter; (2) proxy, those that serve as indirect indicators of an objective that is difficult to measure; and (3) constructed, those that are developed to describe hard-to-measure effects (Gregory and others, 2012).

In SDM, performance measures are often used to describe a predicted outcome of a specific objective, given a management alternative (Gregory and others, 2012). Alternatives in a decision process are complete solutions to the problem (Gregory and others, 2012). Good alternatives are complete and comparable, value focused, defined to a sufficient level of detail, feasible and make logical sense, and are different enough from one another to offer decision makers a choice (Gregory and others, 2012). Alternatives are often developed through brainstorming sessions with stakeholders and generally encompass the full suite of possible actions that can be taken to achieve the objectives. Consequences relate the relative performance of each alternative in terms of the objectives. Therefore, consequence tables are often constructed to convey differences among the alternatives and identify the key trade-offs. Trade-offs are common among decisions that have multiple, often competing objectives and thus involve making judgments about how much a decision maker would relinquish for one objective to achieve gains in another objective (Gregory and others, 2012).

Decisions about the value of objectives are inherently subjective and therefore may differ among stakeholders. Complex decisions that involve alternatives with varying strengths and weaknesses relative to multiple objectives often employ a structured methodology called Multi-Attribute Utility Theory (MAUT). The MAUT model is designed to handle trade-offs among multiple objectives using the concept of linear value modeling. All performance measures must be standardized to the same scale if they are to be comparable, based on their contribution to the overall benefit of the alternative (Kirkwood, 1997; Dyer, 2005). Utility functions (also called value functions; Keeney and Raiffa, 1993; Bell, 2007) are used to standardize performance measures so values related to diverse objectives can be compared on the same scale. The shape of the utility function reflects the relative preference of outcomes across a decision space. Thus, preferences of the decision maker can be viewed along a gradient of possible outcomes in the decision space. The final preference can then be represented by the ordinal additive multi-attribute preference function

$$
\sum_{i=1}^{n}(W i X i) \quad \text { for } i=1,2,3, \ldots, n
$$

where

$$
\begin{array}{ll}
X & \text { is the standardized performance measure } \\
& \text { value of each objective; } \\
W & \text { is the weight of each objective; and } \\
n & \text { is the number of objectives. }
\end{array}
$$

The sum represents the summed benefit of an alternative across all objectives. In this study, we used the concepts described above to develop a spatial value model.

A spatial value model is a type of systematic conservation planning tool defined under one of the five decision support frameworks in Schwartz and others (2018). Following the recommendations of Soulliere and others (2012), some JVs developed their own regional conservation planning tools that included social and biological objectives of conserving and managing waterfowl populations and their habitats. One such example is the spatial conservation planning tool developed by the Upper Mississippi River and Great Lakes Region Joint Venture (Soulliere and Al-Saffar, 2017; Soulliere and others, 2017). Development of this tool loosely followed the SDM framework (Gregory and others, 2012). Work described in this study aims to advance the application of MAUT (Keeney and Raiffa, 1993; Dyer, 2005) at a larger scale (that is, continental) to identify the geographies of greatest importance to waterfowl during the breeding and non-breeding periods as well as geographies that may provide value to people. 


\section{Study Objectives}

There were four specific objectives for the study.

1. Develop a data-based, transparent, and repeatable methodology for deriving spatial products that encompass a "family of maps" for use in identifying geographies of relative importance that are based on combinations of objectives. Additionally, we intend for these to serve as the basis for future NAWMP spatial planning products. Three modes were defined.

a. Use current (2001-15) spatial data to reflect the recent condition of waterfowl populations and exemplify social concerns in North America.

b. Refine and expand on the hierarchy of continental objectives proposed by Soulliere and others (2012).

c. Produce a series of spatial products (that is, family of maps) that emphasize various stages of the waterfowl life cycle (breeding versus non-breeding periods) and incorporate social values as they relate to waterfowl populations and habitat. Spatial data are available in a companion data release (Krainyk, 2019, available at https://doi.org/10.5066/ P9L7J5U4).

2. Provide continental, regional, and province/state decision makers with conservation planning tools (that is, spatial data layers) to aid in resource allocation decisions.

3. Demonstrate how to incorporate biological and social spatial data to identify regions for targeting resources to achieve multiple NAWMP goals.

4. Discuss the application, caveats, and future refinement of these and other spatial products.

Objectives critical for identifying important landscapes were determined through a collaborative process with the Priority Landscapes Committee (PLC; Appendix 1) and other experts and researchers in the field of waterfowl biology and ecology. Spatial data related to waterfowl abundance and distribution during the breeding and non-breeding periods, hunter days afield, obligate wetland bird species diversity, agricultural fertilizer application, land use, and urban centers were acquired from several sources (Supplemental Information). Performance measures, utility functions, and weights for the spatial value model were discussed and agreed on by the PLC. Standardizing performance measures, and weighting and combining spatial layers, were based on the theoretical background of MAUT. ArcGIS Desktop (ESRI, 2011) was used as the platform for managing, analyzing, combining, and displaying the attributes as well as for producing new data through spatial analysis functions. Thirty-eight spatial layers and several composite products were developed on the basis of recommendations of the PLC.

\section{Methods}

\section{Establishing Essential Framework and the Priority Landscapes Committee}

In February 2017, the PLC defined its function and purpose (Appendix 2) and outlined an agenda for committee teleconferencing and interim due dates over a 2-year timeline. Through a series of biweekly teleconferences, the PLC identified primary issues that must be considered when targeting waterfowl habitat conservation while achieving the three fundamental NAWMP goals (NAWMP, 2012). The PLC reasoned that waterfowl habitat delivery is largely a "means objective" to achieve the fundamental objectives for meeting waterfowl population goals and human dimension goals. A workshop held June 27-29, 2017, resulted in the finalization of an objectives hierarchy for developing the family of spatial products and meeting our goal of identifying geographies of greatest importance to waterfowl and people.

\section{Identifying the Problem Statement}

Initial steps by the PLC consisted of clearly defining the problem statement and the associated analysis framework. The fundamental goal was to identify geographies of greatest importance to waterfowl and people in North America, but the exact wording and interpretation of this goal has varied over the years. There has been considerable debate over the use of terms such as "priority," "landscape," and "significant" (Soulliere and others, 2012; Capmourteres and Anand, 2016). The PLC deemed it critical to define the problem using unambiguous terminology that would be the standard for referring to these landscapes of importance. The PLC identified a subset of the waterfowl community that is responsible for resource allocations that affect waterfowl populations and habitat as the decision maker. Waterfowl community was defined as stakeholders who are affected by the designation of North American geographies having various levels of importance to waterfowl and people. They include Federal agencies (that is, U.S. Fish and Wildlife [USFWS], Canadian Wildlife Service [CWS]), state resource agencies, regional waterfowl habitat partnerships (that is, Joint Ventures), non-governmental organizations (that is, Ducks Unlimited [DU], Ducks Unlimited Canada, Ducks Unlimited Mexico), and academic institutions that conduct research on waterfowl and their habitats. The actions that need to be taken were defined as the development of (1) a suite of spatially explicit products representing the performance measures of the defined objectives and (2) composite spatial products consisting of a subset of the objectives. The goal was to identify geographies of continental importance to waterfowl populations and waterfowl habitat conservation supporters. The temporal extent of the problem was defined as the recent (2001-15) timeframe, and the spatial extent 
included continental North America (United States, Canada, and Mexico). Through several discussions, the PLC agreed on the above elements of the decision problem and formulated the following problem statement: Identify geographies of continental importance to waterfowl populations and waterfowl habitat conservation supporters by developing a "family" of spatial products and composite spatial value models that integrate objectives of waterfowl during the breeding and nonbreeding periods and human dimensions.

\section{Identifying Objectives and Developing Objectives Hierarchies}

Identification of a full suite of objectives occurred prior to the initiation of this study through a process of discussions with stakeholders. The objectives were then structured in a means-ends network (Clemen, 1996; Conroy and Peterson, 2013) designed to distinguish between fundamental and means objectives (Keeney, 1992; Edwards and others, 2007; Gregory and others, 2012). The means-ends network (Appendix 3) was developed by the NAWMP Science Support Team (NSST) and NAWMP Interim Integration Committee (IIC) to elucidate the decision context and ensure that concerns of all stakeholder groups were represented in a transparent process. Not all objectives in the means-ends network are fundamental. The means-ends diagram in Appendix 3 (fig. 3.1) is the complete set of objectives (process, strategic, fundamental, and means, inclusive) adopted by the PLC during stakeholder discussions.

When the full suite of objectives was identified, distinctions between biological and social objectives became more apparent. Using the means-ends diagram as a benchmark, the PLC developed an objectives hierarchy, which is based on the fundamental objectives. However, because this project was initiated to develop a spatial value model, the objectives hierarchy did not conform to the traditional definition (Keeney and Raiffa, 1993; Edwards and others, 2007; Gregory and others, 2012). Objective hierarchies typically consist of fundamental objectives with desired directions (that is, increase, decrease) in terms of performance measures. However, in the context of our spatial value model, the goal was to discriminate among regions on the basis of their expected benefit to waterfowl and people through the sum of utility derived from each objective (that is, MAUT concept). Therefore, the PLC grouped the fundamental objectives into two categories: biological objectives related to maintaining continental waterfowl populations and social objectives related to maintaining the tradition of waterfowl hunting and recreational bird watching while providing habitat to support ecosystem services deemed critical to garnering support for waterfowl habitat conservation.

The biological objectives of this study were to

1. Identify landscapes currently (2001-15) important to ducks in North America during the breeding period,
a. Based on breeding duck density,
b. Based on breeding duck abundance, and
c. Based on breeding duck diversity;

2. Identify landscapes currently (2001-15) important to ducks in North America during the non-breeding period,
a. Based on duck use days (DUD) and
b. Based on non-breeding duck diversity;

3. Identify landscapes important to geese and swans in North America during the breeding and non-breeding periods,
a. Based on breeding range overlap of goose and swan species and b. Based on non-breeding range overlap of goose and
swan species.

The following duck species were used to identify important landscapes during the breeding and non-breeding periods: Anas rubripes (American black duck), Anas platyrhynchos (mallard), Anas acuta (northern pintail), Aix sponsa (wood duck), Aythya spp. (scaup), Mareca americana (American wigeon), Anas fulvigula (mottled duck), Spatula clypeata (northern shoveler), Anas crecca (green-winged teal), Spatula discors (blue-winged teal), Mareca strepera (gadwall), Spatula cyanoptera (cinnamon teal), Aythya valisineria (canvasback), Aythya americana (redhead), Aythya collaris (ringnecked duck), Oxyura jamaicensis (ruddy duck), Bucephala albeola (bufflehead), Bucephala spp. (goldeneye), Mergus spp. and Lophodytes cucullatus (merganser), Clangula hyemalis (long-tailed duck), Melanitta spp. (scoter), and Somateria spp. and Polystica stelleri (eider). Abundance estimates for these species were recorded in at least one breeding waterfowl survey following a standardized protocol. Several species of ducks were not used in this analysis, including Anas diazi (Mexican duck), Anas wyvilliana (Hawaiian duck), Anas laysanensis (Laysan duck), Cairina moschata (Muscovy duck), Dendrocygna spp. (whistling duck), Nomonyx dominicus (masked duck), and Histrionicus histrionicus (harlequin duck). Several are present only on the Hawaiian Islands and were considered inappropriate for use in identifying important geographies for waterfowl in continental North America. In addition, some species are not systematically surveyed during the breeding season, including permanent resident species found in Mexico and South America.

The following goose and swan species were used in this analysis: Anser albifrons subspp. (greater white-fronted goose), Branta canadensis subspp. (Canada goose), Branta bernicla subspp. (brant), Anser caerulescens subspp. (snow goose), Anser rossii (Ross's goose), Anser canagicus (emperor goose), Cygnus columbianus (tundra swan), Cygnus buccinator (trumpeter swan), and Cygnus olor (mute swan). Branta sandvicensis (Hawaiian goose) was not included because this species is native to the Hawaiian Islands. 
The social objectives of this study were to

1. Identify landscapes important to waterfowl hunters (related to hunter retention, recruitment, and reactivation),

a. Based on hunter days afield (2001-15) for ducks and geese (related to locations with active hunting communities),

b. Based on travel distance from urban centers $(>5,000$ people);

2. Identify landscapes with impaired watersheds (related to ecological services provided by waterfowl habitat),

a. Based on nitrogen and phosphorus fertilizer applications for crop production,

b. Based on percentage of developed land (that is, urban/suburban, 20- to 100-percent impervious surface); and

3. Identify landscapes important to obligate wetland bird species (related to bird watcher retention, recruitment, and reactivation),

a. Based on range overlap of obligate wetland bird species.

Data for the spatial analysis were acquired from various sources, some available on-line as open access and others elicited from organizations and agencies involved in environmental management decisions (Supplemental Information).

Continental duck populations fluctuate on an annual basis; we therefore used long-term averages (NAWMP, 2004; North American Waterfowl Management Plan Committee, 2014) to index population size for each species. "Species prioritization at continental and regional scales has been the subject of considerable attention and debate. Although lists of priority species have limited potential to directly inform local decisions about where and how to manage habitats, prioritization may provide useful programmatic guidance at regional and continental scales" (NAWMP, 2004). The NSST met in Bismarck, North Dakota, in 2001, to develop a transparent and repeatable methodology for the continental and regional prioritization of waterfowl species, and results appeared in the NAWMP (2004). The prioritization methodology was based on two factors - (1) population trend or vulnerability to population decline and (2) socioeconomic importance (NAWMP, 2004, see Appendix B for full methodology).

The PLC used this prioritization process as the benchmark for grouping duck species according to "management guilds" on the basis of feeding and nesting strategy, while acknowledging that some species warrant greater attention and thus should stand alone (Appendix 4). These last species were termed "focal species" and defined as species of special concern or those that waterfowl partnerships directly manage through species-specific management plans. Resource managers frequently manipulate habitat conditions for specific groups of migratory birds, often within the same guild (Nudds, 1983; Soullier and others, 2017). Species in the same guild are assumed to derive some population benefits from habitat initiatives directed at specific habitat types (for example, many ground nesting dabbling ducks have similar breeding and non-breeding habitat requirements; Nudds, 1983).

Species of geese and swans were considered separately from ducks because of discrepancies in data availability and differences in population limiting factors (that is, most goose and swan populations are not considered habitat limited) and because some goose populations are considered overabundant. Although several population abundance surveys are available for breeding geese, these are often not as extensive, consistent, or long term as those for ducks. Subspecies were not differentiated because consistent breeding abundance data for each subspecies were unavailable. In wildlife habitat modeling, limited data and an incomplete understanding of the system is common (Holling, 1978), but models can still be useful tools for decision making and especially for identifying and prioritizing efforts to address information gaps (Millspaugh and Thompson, 2011). The PLC believed that including available distribution data for geese and swans may improve the spatial value model's ability to identify geographies of continental importance to waterfowl, while also offering insights into future refinements of the model. Although most populations of geese and swans (Appendix 5) are currently above population targets (NAWMP, 2012), the PLC recognized that two species (emperor goose and brant) are below continental population target and require special attention at the regional level.

The need to include social concerns in conservation decisions led the waterfowl community to establish a Human Dimensions Working Group (HDWG). A primary function of the HDWG is to help advance the understanding of how waterfowl habitat conservation can help achieve objectives that are important to people. Preliminary reports by the HDWG provide a foundation for development of social objectives by the PLC. During the PLC stakeholder input workshop (June 27-29, 2017), participants identified three groups of waterfowl habitat conservation supporters: waterfowl hunters, bird watchers, and the general public and landowners. Hunters provide financial and political support for waterfowl habitat conservation. For example, hunters are required to purchase government issued waterfowl habitat conservation stamps in Canada and the United States, generating hundreds of millions of dollars annually. Since 1934, funding from the Migratory Bird Hunting Stamp Act in the United States (Federal "duck stamp" sales) has been directed to waterfowl habitat conservation via the Migratory Bird Conservation Fund. Bird watchers may also voluntarily purchase duck stamps, but there are currently no mandates for bird watchers to provide financial support for waterfowl habitat conservation. Although some tax revenues from the general public are used to fund Federal programs (that is, Canada Nature Fund), generally the public provides little direct financial support. Nevertheless, the public can be an instrumental stakeholder group in galvanizing 
political support for habitat conservation projects that affect ecosystem services provided by wetlands and associated habitats. Recognizing the different levels of support (financial and political) of these stakeholder groups, the PLC identified objectives specific to each group of conservation supporters. However, the PLC also recognized that there is high uncertainty regarding the assumption that conservation support translates to conservation capital or opportunity (Clark and others, 2015).

Distance to urban centers was identified as an important factor in determining opportunity for potential hunting and bird watching trips (Devers and others, 2017; HDWG, unpub. data, 2018, https://nawmp.org/documents). The HDWG's preliminary results indicate that hunters prefer to travel less than 80 kilometers $(\mathrm{km})$ for day hunting trips. The PLC used an $80-\mathrm{km}$ distance around urban centers to identify geographically important landscapes where accessible waterfowl habitat would result in greater hunting opportunities and an assumed increase in waterfowl conservation support. Beyond hunting, focusing on waterfowl habitat in locations close to human population centers may have a beneficial effect on conservation support from the general public. For bird watchers and others seeking opportunities to reconnect with nature, the availability and use of wetlands could encourage their interest in, and support for, waterfowl habitat conservation. The PLC determined that minimizing distances between waterfowl habitat and urban centers was the first fundamental social objective.

The distribution of hunter days afield was also considered an important factor in identifying priority landscapes for conservation, as this measure reflects the intensity of hunting activity and is assumed to be a useful index for distribution of the waterfowl hunting community. Areas with currently active waterfowl hunting communities are necessarily the areas where hunters (and their conservation support) are most likely to be retained. We assumed these areas provide greater opportunities for hunter recruitment. Finally, waterfowl hunters have greater satisfaction when abundance and diversity of waterfowl are high (HDWG, unpub. data, 2018, https://nawmp.org/ documents). Since waterfowl abundance (density) is reflected in the biological objectives, the PLC considered only waterfowl diversity as a social objective. Waterfowl diversity was an important factor in waterfowl hunter satisfaction, whereas bird diversity, in general, was an important indicator of bird watcher satisfaction. However, since this study was set in the context of waterfowl habitat conservation, we determined that obligate wetland bird diversity would serve as a surrogate for bird watcher satisfaction. Additionally, it is important to note that social objectives identified herein are assumed to increase satisfaction among hunters and bird watchers. Although there is an assumed correlation between satisfaction and recruitment, retention, and reactivation, this hypothesis has not been tested.

The HDWG found that conservation support may also come from the general public. Waterfowl habitat provides important ecosystem services such as flood abatement, water-quality maintenance and improvement, and carbon sequestration; therefore, preservation of waterfowl habitat can draw financial and political support from an informed public. The inclusion of ecosystem services in assessments of conservation priority areas (Egoh and others, 2007) has received growing attention by conservation planners (de Groot and others, 2010). The PLC identified nitrogen and phosphorus fertilizer application (primarily row-crop agricultural lands) as an important indicator of watershed impairment. We assumed that this, coupled with percentage of land classified as developed (urban/suburban), serves as an indicator of watershed quality and impairment. Thus, we developed an objective of reducing watershed impairment, which would be addressed by focusing waterfowl habitat (that is, wetland) conservation resources on watersheds of highest impairment status (that is, those with the highest percentage of developed land and large amounts of fertilizer application).

All social objectives were developed with the notion that the increasing relevance of conservation and associated satisfaction of waterfowl hunters, bird watchers, and the general public would ultimately increase financial and political support for waterfowl habitat conservation. Several assumptions are implicit in this belief-(1) decreasing travel distance between accessible waterfowl habitat and urban centers will reduce travel time and increase hunter and bird watcher opportunity and satisfaction; (2) focusing resources in areas with relatively high levels of hunter days afield helps meet hunt-area needs and satisfaction for the current waterfowl hunting community (retention), which plays a critical role in expanding the number of waterfowl hunters (recruitment and reactivation); and (3) enhancing ecosystem services provided by waterfowl habitat improves the quality of life and satisfaction for local citizens, thereby increasing the likelihood of financial or political support for waterfowl habitat conservation. The social objectives hierarchy is represented in visual form in Appendix 6.

\section{Selecting Performance Measures and Data Sources}

The PLC determined that biological objectives should reflect important areas for breeding waterfowl populations and production habitat, as well as areas of high importance for waterfowl foraging (dietary energy) during the non-breeding period (migration and winter). Moreover, discussion among PLC members revealed that two performance measures were most relevant for habitat planning in the breeding range. Abundance and density of waterfowl can each be used to justify resource allocation. We therefore calculated both abundance and density of each duck species and management guild $(n=9)$ at the $50 \times 50 \mathrm{~km}$ grid scale. This scale was chosen by the PLC as a result of exploratory analysis at scales of $1 \times 1 \mathrm{~km}, 10 \times 10 \mathrm{~km}, 50 \times 50 \mathrm{~km}, 100 \times 100 \mathrm{~km}, 250 \times 250 \mathrm{~km}$, and $1,000 \times 1,000 \mathrm{~km}$. The first two scales were too small and added substantial computer processing time but did not add 
significant visual resolution to the map product. In contrast, the $100 \times 100 \mathrm{~km}, 250 \times 250 \mathrm{~km}$ and the $1,000 \times 1,000 \mathrm{~km}$ scales were too coarse, and the visual resolution of the output maps was considered unacceptable.

Abundance of waterfowl is defined as the number of breeding ducks in a 2,500-square-kilometer $\left(\mathrm{km}^{2}\right)$ grid cell (that is, $50 \times 50 \mathrm{~km}$ area). Density is defined as the number of breeding waterfowl per $\mathrm{km}^{2}$. Breeding waterfowl data were compiled from various sources (Supplemental Information). We attempted to limit analysis to only survey data that were collected between 2001 and 2015, which we assumed would reflect the most current distribution and density of breeding waterfowl. Several well-known and long-term surveys, such as the Waterfowl Breeding Population and Habitat Survey in the Traditional Survey Area and Eastern Survey Area, were used as a primary data source (U.S. Fish and Wildlife Service, Division of Migratory Bird Management, https://migbirdapps. fws.gov/mbdc/databases/mas/maydb.asp?opt=maydb). Additionally, data from several species-specific and state breeding waterfowl surveys, such as the Western Gulf Coast Mottled Duck Survey and Oregon Breeding Waterfowl Survey, were obtained from various state and Federal agencies. In all, more than 20 different breeding waterfowl abundance surveys were utilized to develop spatial layers depicting the geographies most important for ducks during the breeding period. For a full list of breeding waterfowl surveys used and their sources refer to the Supplemental Information.

Conservation planning and management for ducks during the non-breeding period typically relies on bioenergetic modeling to determine the capacity of a given landscape to support waterfowl populations. For most Nearctic ducks, the non-breeding period extends nearly eight months and includes significant biological and social events whose timely completion can be affected by access to high quality food and disturbance-free areas (Whyte and Bolen, 1984; Baldassarre and Bolen, 2006; Legagneux and others, 2009; Dooley and others, 2010; Davis and others, 2014). For the non-breeding period, the PLC believed that areas of importance for ducks should be delineated on the basis of expected use during autumn-winter, which generally should reflect non-breeding habitat quality and its contribution to the energetic needs of ducks. Ducks Unlimited scientists utilized NAWMP stepdown population objectives (Fleming and others, 2017) and speciesspecific migration curves constructed from eBird data to calculate the number of duck use days (DUD) an area would be expected to support, at the county scale, for target populations of waterfowl during the non-breeding period (Fleming and others, 2017; Brasher and others, Ducks Unlimited, written commun., 2018). The concept of DUDs represents the theoretical use of any area by one individual duck for one day. Cumulative DUD values for this analysis were based on a 242-day planning period (September 1-April 30) and accounted for the estimated duration of stay for each species within a county. The PLC reasoned that focusing habitat conservation in areas of high DUDs would be important for supporting NAWMP population goals during the non-breeding period.
Although some breeding population surveys are available for geese and swans, they were seldom conducted annually and cover only parts of the breeding ranges (Kerbes and others, 2014; Wilson, 2017). Many goose species breed in the high Arctic, where access, even by fixed-wing aircraft, may be difficult. Therefore, data limitations for goose and swan species prevented us from developing accurate measurements of breeding population abundance and density. However, the lack of data should not be used as justification to exclude objectives that matter to the stakeholders (Millspaugh and Thompson, 2011). Furthermore, the PLC believed that most goose species are not limited during the non-breeding period by resource availability. To the contrary, some geese are overabundant and take advantage of agricultural crops, causing damage and potentially limiting resources for duck species at some locations (Batt, 1997; Vrtiska and Sullivan, 2009; Webb and others, 2010). After much discussion, the PLC decided adequate spatial layers depicting breeding and non-breeding goose and swan distributions were available via NatureServe database (BirdLife International, http://datazone.birdlife.org/ species/requestdis). Future refinement of goose and swan distribution maps might include filtering spatial population data by land-cover classification, including only areas consisting of recognized habitats (for example, emergent wetland and open water in the U.S. Geological Survey 2010 Landcover of North America at 250 meters, 2010, https://catalog.data.gov/ dataset/2010-land-cover-of-north-america-at-250-meters). The average number of breeding and non-breeding goose and swan species (that is, the number of species ranges overlapping a geography) was accepted as a temporary performance measure with the assumption that these spatial layers would be updated as more accurate and consistent breeding and non-breeding goose and swan survey data become available.

The field of social science related to human behavior and values toward wildlife and habitat conservation is extensive (see Decker and others, 2012). However, there are few examples of the integration of social values into waterfowl habitat conservation design and decisions (Nelson and others, 2009; Soulliere and Al-Saffar, 2017). Wildlife habitat conservation is a representation of social values, and purposely excluding the needs of people from conservation design will have a negative effect on public support, both financial and political. The 2012 NAWMP explicitly recognized this requirement and directed that future waterfowl habitat conservation efforts should strive to integrate social values. The predicted financial and political support of each stakeholder group varies on the basis of several assumptions (Clark and others, 2015). The PLC sought to define performance measures that best identified where resource investments in waterfowl habitat conservation could benefit multiple stakeholder groups.

To evaluate habitat conservation initiatives on the basis of travel distance from human population centers, a natural performance measure of kilometers was deemed the most appropriate. Geographies within 80 kilometers (HDWG, unpub. data, 2018, https://nawmp.org/documents) of urban centers were considered the highest priority for waterfowl habitat 
conservation to better meet the public demand for hunting and bird watching trips. The spatial representation of this performance measure required acquisition of three spatial layers depicting urban centers in Canada, United States, and Mexico. The urban extent was based on a combination of population counts, settlement points, and presence of nighttime lights. Areas were defined as urban where contiguous lighted cells from the nighttime lights or approximated urban extents, based on buffered settlement points for which the total population is greater than 5,000 persons (Balk and others, 2006). The choice of this spatial layer reflects the assumption outlined by Clark and others (2015) that "Regional recreation objectives are determined in part by the size and distribution of population centers (5,000 people or larger) and their proximity to wetland areas."

Breeding and non-breeding waterfowl diversity, which was assumed to increase hunter satisfaction, was represented by the Simpson's Reciprocal Index of Species Diversity (Simpson, 1949). The PLC chose this as the natural performance measure because it was deemed to accurately represent diversity and composition of waterfowl species during the breeding and non-breeding periods. Two spatial layers were created, each based on breeding population abundance and non-breeding abundance (calculated from DUD). The HDWG found that bird watcher satisfaction increased with bird diversity. Although waterfowl diversity (breeding and non-breeding) may be important to hunters, it does not fully represent the species diversity of obligate wetland birds. The PLC accounted for this discrepancy by identifying obligate wetland bird diversity as a sub-objective for the bird watcher stakeholder group. As a performance measure, the average number of obligate wetland bird species was used to depict geographies of relatively high wetland bird species diversity and, thus, areas that would increase bird watcher satisfaction and potential support for waterfowl habitat conservation. Spatial data for 169 obligate wetland bird species (North American Bird Conservation Initiative, 2011) were gathered from NatureServe database (BirdLife International, 2016, http://datazone.birdlife.org/species/requestdis) and provided the basis for determining the average number of species in $10 \times 10 \mathrm{~km}$ blocks across North America.

For evaluating areas of conservation efforts to reduce the impairment status of watersheds, the PLC developed two performance measures. The PLC believed that impairment status could be reduced most (and wetland health and function improved most) where the percentage of developed land cover was greatest and the nitrogen and phosphorus fertilizer applications for agricultural purposes were highest. Key assumptions governing these decisions were that resource allocations to waterfowl habitat (that is, wetlands) would (1) reduce the effect on watersheds from sediment run-off, thereby, improving water quality; (2) increase services gained from wetland ecosystems (that is, flood abatement, water purification) near areas of high urban development; and (3) mitigate existing waterbody (wetland, river, lake) eutrophication and contamination resulting from high nitrogen and phosphorus fertilizer applications. Nitrogen and phosphorus fertilizer application spatial data were obtained from the Socioeconomic Data and Applications Center (http://sedac.ciesin.columbia.edu/maps/ gallery/search?facets=theme:agriculture \&facets=region:nor thAmerica). The spatial data represented nitrogen and phosphorus application (in kilograms per hectare) at a 0.5 -degree scale. The data source used to calculate percentage of urban developed land is the North American Land Change Monitoring System Collection (U.S. Geological Survey, 2010, https:// catalog.data.gov/dataset/2010-land-cover-of-north-america-at250-meters). The dataset contains 20 land-cover classes, one of which is Developed and Built Up.

Lastly, hunter days afield represent current recreational waterfowl hunting activity and serve as a proxy performance measure for relative size and distribution of the active waterfowl hunting community across North America. For the United States, hunter days afield data were collected through the USFWS Migratory Bird Hunter Survey (Raftovich and others, 2017), and duck and goose hunter days afield were estimated separately at the county level. Hunter days afield data for Canada were provided by the Canadian Wildlife Service National Harvest Survey (https://wildlife-species.canada.ca/ harvest-survey/?do=def\&lang=e), although they are reported as total waterfowl hunting days at the Provincial hunting zone scale. Comparable data for Mexico were not available. Owing to the discrepancies in the data for the three nations, this performance measure needs to be treated with caution, as it provides only a preliminary representation of the waterfowl hunting community and levels of activity and demand. Limitations to inference from these data are described in section "Benefits, Limitations, and the Future" of this report.

Following the collection of all data, the PLC developed spatially explicit layers to represent geographies of relative importance at the continental scale for each objective separately. The general description for the development of spatial layers is in the section "Developing Spatial Layers." For an in-depth step-by-step explanation of development, please refer to the Supplemental Information.

\section{Developing Spatial Layers}

ArcGIS Desktop (ESRI, 2011) was used as the platform to develop all spatial layers. Data for all waterfowl surveys were compiled into species/guild-specific Microsoft Excel 2010 spreadsheets. The accuracy, consistency, and availability of survey data varied. Therefore, population estimates were calculated at the survey strata levels. Population estimates for breeding ducks were assigned to their specific survey strata and displayed in ArcGIS (ESRI, 2011). All areas where no survey data existed were assigned a "No Data" classification. The PLC recognized that "No Data" designations did not necessarily indicate the absence of breeding ducks; these areas were therefore assigned a value of less than 0.001 to convey that breeding ducks may be present but likely in low abundance. Finally, species/guild-specific breeding abundances and densities were calculated for each $50 \times 50 \mathrm{~km}$ grid cell. 
In-depth explanations and methodologies for developing spatial layers depicting landscapes of relative importance to nine duck species/guilds during the breeding period are presented in Supplemental Information.

Estimates of DUDs were used to develop spatial layers depicting the relative importance of geographies for nonbreeding ducks. DUD data for each species were available at the county level for the United States and at the degree block (0.5-degree block) scale for some areas in Canada and Mexico (see Supplemental Information). We used these data to calculate the density of DUDs (DUD/ $\mathrm{km}^{2}$ ) and then transformed the values to total DUDs at the $50 \times 50 \mathrm{~km}$ scale. For species that fall within management guilds, DUDs were summed for all species within the guild at the county level, prior to transformation. In-depth explanations and methodologies for developing spatial layers depicting landscapes of relative importance to nine duck species/guilds during the non-breeding period are presented in Supplemental Information.

Breeding goose and swan distribution spatial layers from the NatureServe database (BirdLife International, 2016, http:// datazone.birdlife.org/species/requestdis) were converted from vector to raster with $1 \times 1 \mathrm{~km}$ cell resolution and summed using the Cell Statistics tool in ArcGIS (ESRI, 2011). The resulting spatial layer indicated the number of breeding goose and swan species at any given area in North America. The non-breeding goose and swan distribution vector layers also were converted to rasters with $1 \times 1 \mathrm{~km}$ cell resolution and summed using the Cell Statistics tool in ArcGIS (ESRI, 2011). The resulting spatial layer indicated the number of non-breeding goose and swan species at any given area in North America. Indepth explanations and methodologies for developing spatial layers depicting landscapes of relative importance to geese and swans during the breeding and non-breeding periods are presented in Supplemental Information.

The spatial layer for human population centers was developed by merging the Canadian, United States, and Mexican spatial files representing urban centers. The Euclidean Distance tool in ArcGIS (ESRI, 2011) was used to create a continuous raster dataset with $1 \times 1 \mathrm{~km}$ cell resolution displaying the distance of any cell in the raster from the nearest urban center. In-depth explanations and methodologies for developing spatial layers depicting landscapes of relative importance to waterfowl habitat conservation supporters, based on distance from urban centers, are presented in Supplemental Information.

Breeding and non-breeding duck diversity layers were created using the spatial layers produced for breeding abundance and total DUDs. At each 50×50 km grid block, Simpson's Reciprocal Index of Species Diversity (Simpson, 1949) was calculated on the basis of abundance and composition of breeding ducks and on abundance and composition of nonbreeding ducks (calculated from DUD and a 242-day planning period). Obligate wetland bird diversity was defined as the average estimated number of obligate wetland bird species present (represented by distribution data) at a $10 \times 10 \mathrm{~km}$ grid scale. Spatial layers depicting the distribution of 169 obligate wetland bird species were converted to rasters with $1 \times 1 \mathrm{~km}$ cell resolution, then summed using the Cell Statistics tool in ArcGIS (ESRI, 2011). In-depth explanations and methodologies for developing spatial layers depicting landscapes of relative importance to waterfowl habitat conservation supporters based on species diversity are presented in Supplemental Information.

Performance measures to evaluate impairment status of watersheds were developed using nitrogen and phosphorus fertilizer application spatial data (Socioeconomic Data and Applications Center [SEDAC], 2010, http://sedac.ciesin. columbia.edu/maps/gallery/search?facets=theme:agriculture \&facets=region:north America) and the North American Land Change Monitoring System Collection data (U.S. Geological Survey, 2010, https://catalog.data.gov/dataset/2010-landcover-of-north-america-at-250-meters). The spatial layers for nitrogen and phosphorus application were added using the Cell Statistics tool in ArcGIS (ESRI, 2011). The average input of agricultural fertilizer (phosphorus and nitrogen) was calculated at the $10 \times 10 \mathrm{~km}$ grid scale using Zonal Statistics tools in ArcGIS (ESRI, 2011). The North American Land Change Monitoring System Collection (U.S. Geological Survey, 2010, https://catalog.data.gov/dataset/2010-land-cover-of-northamerica-at-250-meters) spatial dataset was reclassified. The class Developed and Built Up landscapes received a value of 1 , and all other land-cover classes received a value of 0 . The percentage of land in the Developed and Built Up class was calculated at the $10 \times 10 \mathrm{~km}$ grid scale using Zonal Statistics tools in ArcGIS (ESRI, 2011). In-depth explanations and methodologies for developing spatial layers depicting landscapes of relative importance to waterfowl habitat conservation supporters, based on watershed impairment, are presented in Supplemental Information.

Hunter days afield data for the United States were separated by ducks and geese. The average for ducks and geese from 2005 to 2016 was calculated separately at the county scale to reflect the level of activity by the waterfowl hunting community across the United States. These averages were assigned to their respective counties using unique identifiers in ArcGIS. Waterfowl hunter days afield for Canada were averaged at the provincial hunting zone scale for 2001-16. These values were then assigned to their respective hunting zone in ArcGIS. In-depth explanations and methodologies for developing spatial layers depicting landscapes of relative importance to waterfowl habitat conservation supporters, based on hunter days afield, are presented in Supplemental Information.

Data for all biological objectives (breeding and nonbreeding ducks/guilds, and geese and swans) were summarized at the $50 \times 50 \mathrm{~km}$ scale, which was the best resolution for biological objectives given the available data. Data related to all social objectives were summarized at the $10 \times 10 \mathrm{~km}$ scale, but most of these spatial layers had resolutions that ranged from $30 \times 30$ meter to $10 \times 10 \mathrm{~km}$ scales. Therefore, summarizing social data at the same scale as biological data would result in a loss of resolution. 


\section{Developing Utility Functions and Standardization of Spatial Layers}

The biological and social objectives outlined thus far have different performance measures. However, the MAUT as it applies to spatial value models requires that performance measures be converted to a standardized scale for comparison and aggregation (Kirkwood, 1997; Dyer, 2005; Gregory and others, 2012). Although some biological objectives share the same performance measure (that is, density of breeding species/guilds), they are not readily comparable. For example, a waterfowl habitat conservation initiative that seeks to maximize duck breeding densities may value the density of one species above another. The PLC agreed that some species hold higher value to various stakeholders owing to factors such as low population abundance (species of conservation concern) or high recreational demand (species most pursued by hunters). All utility functions in this spatially explicit value model were developed on the basis of an informal process similar to the "desirability curves" of Hammond and others (1999) to determine the form of each utility function (for example, increasing or decreasing; linear, concave, or step) relating the original attribute scale to the utility scale with support of assumptions by expert opinion, unpublished preliminary results of the HDWG (https://nawmp.org/documents), and primary literature.

Breeding duck density utility functions were based on the decile distribution of the range of densities at the species/ guild-specific level. Densities for nine species/guilds were calculated in the section "Selecting Performance Measures and Data Sources," and the range of densities for each species was then used to divide the densities into deciles. The range of densities was used to identify the inflection points (that is, the $\mathrm{x}$-axis values) for the piece-wise linear utility function (Kirkwood, 1997). The y-axis was the utility measure (ranging from 0 to 1 ). All breeding duck density utility functions were concave, increasing in utility rapidly and then plateauing (see Supplemental Information).

Non-breeding DUD utility functions were based on cumulative DUD values. For each of nine species/guilds, the distribution and range of total DUD were sorted in ascending order, then the cumulative DUD was calculated on the basis of 20 -percent breaks. The total DUD value at each percentile bin break (that is, 20,40, 60, and so on) was used as the inflection point (that is, the $\mathrm{x}$-axis values) for the piece-wise linear utility function. The y-axis was the utility measure (0 to 1$)$. All nonbreeding DUD utility functions were concave, increasing in utility rapidly and plateauing (see Supplemental Information).

Breeding and non-breeding goose and swan utility functions were based on the average number of breeding and nonbreeding goose and swan species. Inflection points were based on PLC discussion, and the piece-wise linear utility functions resembled an S-shaped curve. The breeding goose and swan utility function had six inflection points (that is, the x-axis values), and the non-breeding goose and swan utility function had seven inflection points (that is, the $\mathrm{x}$-axis values).
The piece-wise linear utility function for the distance to urban centers objective was based on preliminary results of the HDWG (unpub. data, 2018, https://nawmp.org/documents). The inflection points were determined by the PLC through discussion and references to the HDWG findings. Utility functions for the remainder of the social objectives were developed using decile breaks of the distribution of values for each performance measure. For the full methodology and the piece-wise linear functions for all performance measures, see Supplemental Information.

Through the development of utility functions, we were able to standardize each spatial layer to the same utility scale ranging from 0 to 1 . This process allowed us to assign weights to each performance measure and aggregate the individual spatial layers into several final products.

\section{Weights and Final Products}

Many applications of SDM are based on the concept of linear value modeling (Gregory and others, 2012) and thus represent an alternative's performance score as the weighted sum of its consequences. The spatial value model described herein does not adhere to the strict definitions under SDM. There are no specified alternatives because there are no defined management decisions; therefore, there are no predicted consequences of alternatives. Nonetheless, MAUT can be applied because the mathematical representation of the spatial value model is the same as for any other SDM tool that employs MAUT:

$$
\begin{gathered}
\text { Overall pixel score }=W_{i} X_{i}+W_{i} X_{i}+ \\
W_{i} X_{i} \quad \text { for } i=1,2,3 \ldots, n
\end{gathered}
$$

where

$$
\begin{array}{cl}
n & \text { is the number of objectives } \\
W_{i} & \text { is the weight assigned to each objective } i \text { and } \\
X_{i} & \text { is the utility value for objective } i \text {, based } \\
\text { on its performance measure (see section } \\
\text { "Structured Decision Making" for } \\
\text { description of additive multi-attribute } \\
\text { preference function). }
\end{array}
$$

The spatial value model is additive; therefore, the weights of all objectives included in the model equals a maximum of one. The overall score will differ from pixel to pixel in our spatial model because the utility of each objective differs. However, the weight assigned to each objective is constant. Weights can be defined with a variety of methods (Kirkwood, 1997; Brown and others, 2001), some supported by literature, whereas others are based on expert opinion. However, all weights are subjective because they describe the degree to which a decision maker values one objective versus another. The PLC determined that five spatial value models would be produced to represent the relative importance of geographies to (1) waterfowl during the breeding and non-breeding periods, (2) waterfowl during the breeding period, (3) waterfowl during 
the non-breeding period, (4) waterfowl habitat conservation supporters, and (5) waterfowl and waterfowl habitat conservation supporters. The number of spatial layers and the weight assigned to each objective differed among the five models produced. The PLC determined that they could not, with confidence, ascertain regional preferences for all objectives without extensive input from regional experts and stakeholders. Therefore, what we deemed "default weights" were assigned to demonstrate the application of these models under a scenario where each objective was weighted (that is, valued) equally. Clearly, weights will vary for attributes, depending on the decision problem under consideration. The spatial layers and their respective default weights for each of the five spatial products are available in the Supplemental Information.

Spatial layers representing performance measures, normalized through unique utility functions for each objective as described above, were multiplied by their respective weights (Supplemental Information) and converted to $1 \times 1 \mathrm{~km}$ raster files; ArcGIS Desktop was used as the platform for calculating the overall utility score (equation 2 ) at the pixel level. This process was repeated five times, each time using the normalized spatial layers selected for each of the individual spatial products and a different distribution of weights (Supplemental Information) with a maximum possible overall score of one.

\section{Results}

Although only five spatial products (that is, the family of maps) were produced for this report, we acknowledge that there are an infinite number of spatial products that could be produced by varying the number of objectives and their weights to generate mixed-model output maps that aggregate social and biological objectives. However, given our interest in identifying geographies most significant to waterfowl and waterfowl habitat conservation supporters, the five products listed in this section were deemed the most appropriate in the context of achieving NAWMP goals.

Geographies of relatively highest importance to North American waterfowl during the combined breeding and nonbreeding periods are the Prairie Pothole Region; the Midwest and northeastern United States; Mississippi Alluvial Valley; United States western gulf coast; California Central Valley; parts of Alaska, Washington, and Oregon; and the Canadian Boreal Forest (fig. 3). Areas of lowest relative importance are in the high Arctic, along the Rocky Mountains in Canada, and most of Mexico. However, the lack of adequate breeding waterfowl survey data from Mexico limited our ability to differentiate among areas of high and low importance in Mexico. Therefore, some areas of apparent low importance in Mexico may simply be due to data limitations, whereas other areas of low importance are known to be non-significant areas for waterfowl. Data limitations are discussed in section "Benefits, Limitations, and the Future."

Geographies of relatively highest importance to waterfowl during the breeding period were the Prairie Pothole
Region; northeastern United States and southeastern Canada; parts of Alaska, British Columbia, Washington, Oregon, and California; and the Canadian Boreal Forest (fig. 4). Some areas of apparent lowest relative importance were the high Arctic and Mexico. Again, our ability to differentiate among areas of high and low importance for breeding waterfowl in Mexico may be a reflection of data limitations rather than a representation of true conditions.

Geographies of relatively highest importance to waterfowl during the non-breeding period were along the United States Atlantic coast, Midwest and northeastern United States, Mississippi Alluvial Valley, United States and Mexico gulf coast, California Central Valley, Intermountain West, United States Pacific Northwest, and parts of the Pacific Coast of Mexico (fig. 5). Additionally, the spatial product depicts north-south migration corridors as non-breeding geographies of moderate importance. Areas of lowest relative importance to non-breeding waterfowl are northern Canada, the Rocky Mountain Range in Alaska and Canada, eastern Canada, and parts of southern Mexico. These regions of lowest importance in Mexico are likely based on lack of data for duck use days, a limitation discussed in the "Discussion" section.

Geographies of relatively highest importance to waterfowl conservation supporters were the Midwest United States, southern Canada, United States Atlantic coast, Mississippi Alluvial Valley, United States western gulf coast, California Central Valley, Intermountain West, and United States Pacific Northwest (fig. 6). Regions in Mexico depicted as having moderate importance were potentially affected by lack of data for hunter days afield, one of the social objectives for which data were available in Canada and the United States. The area of lowest relative importance regarding current and potential conservation supporters was the high Arctic. This is not surprising because of low human densities, few hunters, lower wetland bird diversity, and relatively unimpaired watersheds. However, First Nation people in some Arctic geographies directly depend on waterfowl for subsistence and cultural values, and in these areas, other potentially unique factors need to be considered in conservation decision making.

Geographies of relatively highest importance to waterfowl populations and potential waterfowl conservation supporters were the Prairie Pothole Region, Midwest and northeastern United States, Canadian Maritime Provinces, Mississippi Alluvial Valley, United States western gulf coast, California Central Valley, Intermountain West, and United States Pacific Northwest (fig. 7). Areas of relatively lower importance are the high Arctic, northern Canada, and parts of Mexico. Lower relative importance scores may be due, in part, to waterfowl population and hunter days afield data limitations.

Many of the same geographies were identified as high relative importance for waterfowl and waterfowl habitat conservation supporters. Areas of apparent low relative importance may be biased low owing to data limitations and can be used to identify gaps in knowledge and survey efforts. 


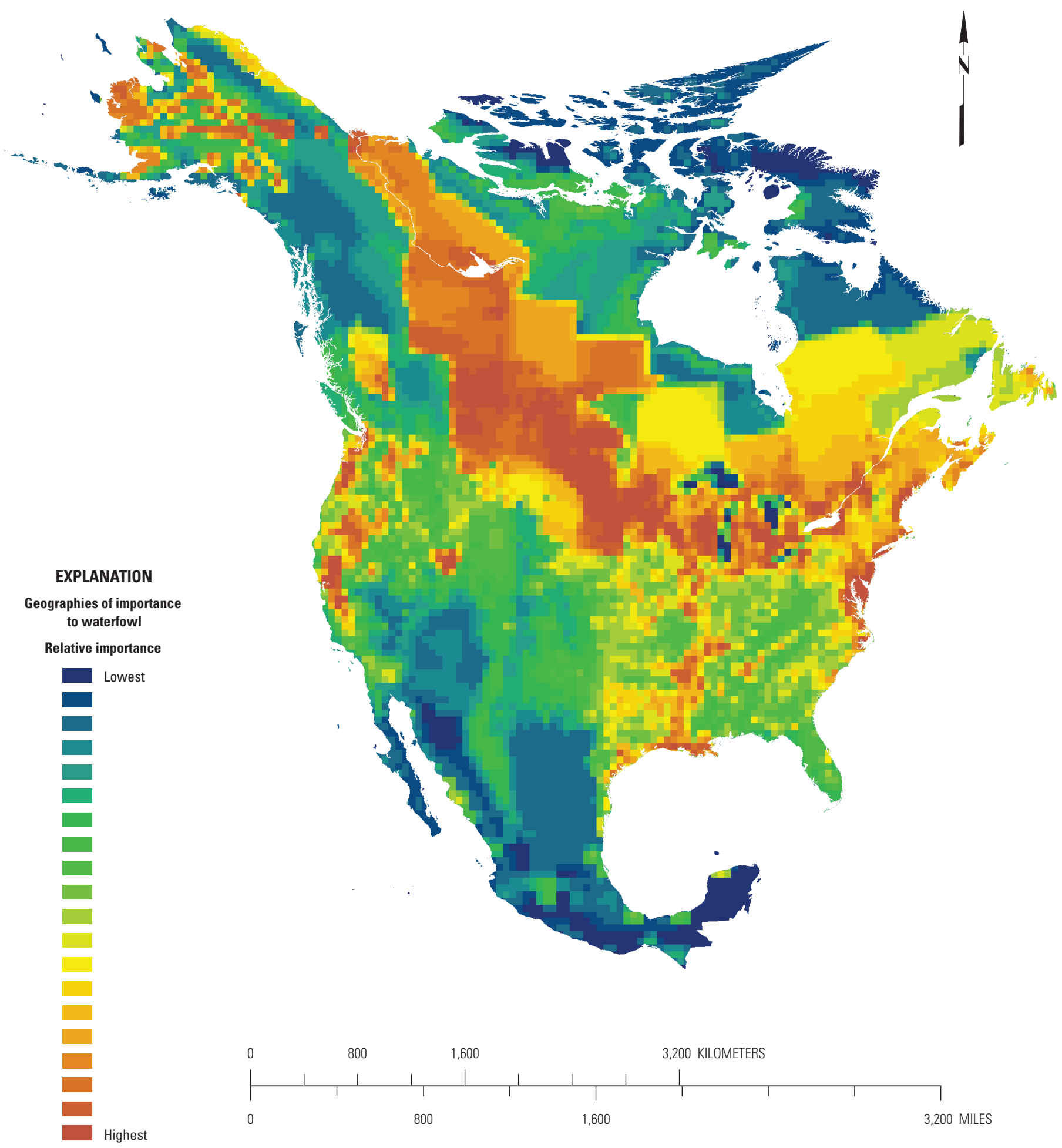

Figure 3. Relative importance of geographies to waterfowl during the breeding and non-breeding periods. The spatial product is an aggregation of 20 biological objectives (breeding and non-breeding mallard, American black duck, northern pintail, scaup spp., wood duck, dabbling ground nester guild, diving overwater nester guild, diving cavity nester guild, diving ground nester guild, and geese and swans), each with equal weight of 0.05 . 


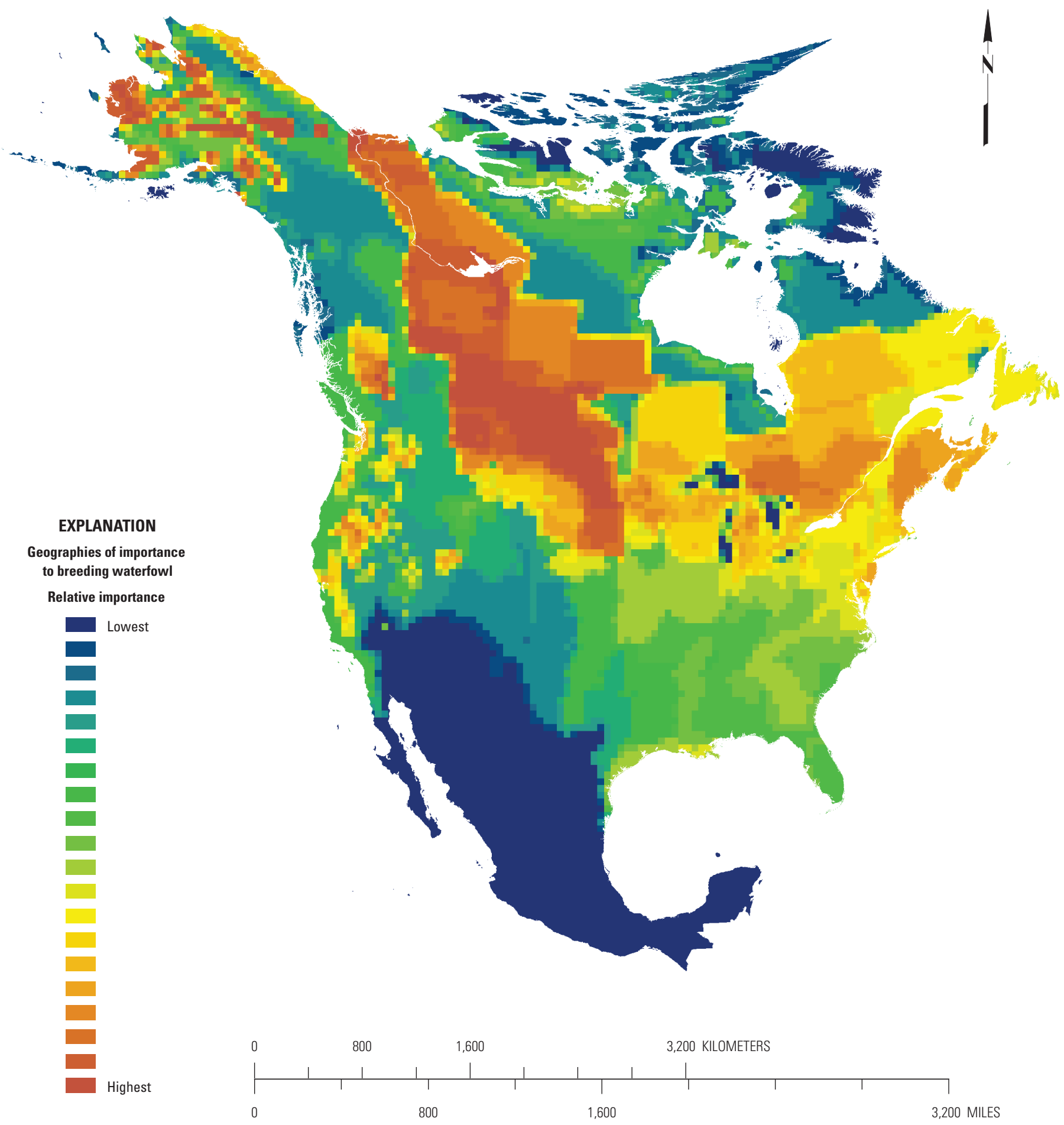

Figure 4. Relative importance of geographies to waterfowl during the breeding period. The spatial product is an aggregation of 10 biological objectives (breeding mallard, American black duck, northern pintail, scaup spp., wood duck, dabbling ground nester guild, diving overwater nester guild, diving cavity nester guild, diving ground nester guild, and geese and swans), each with equal weight of 0.1. (No breeding duck data were available for Mexico). 


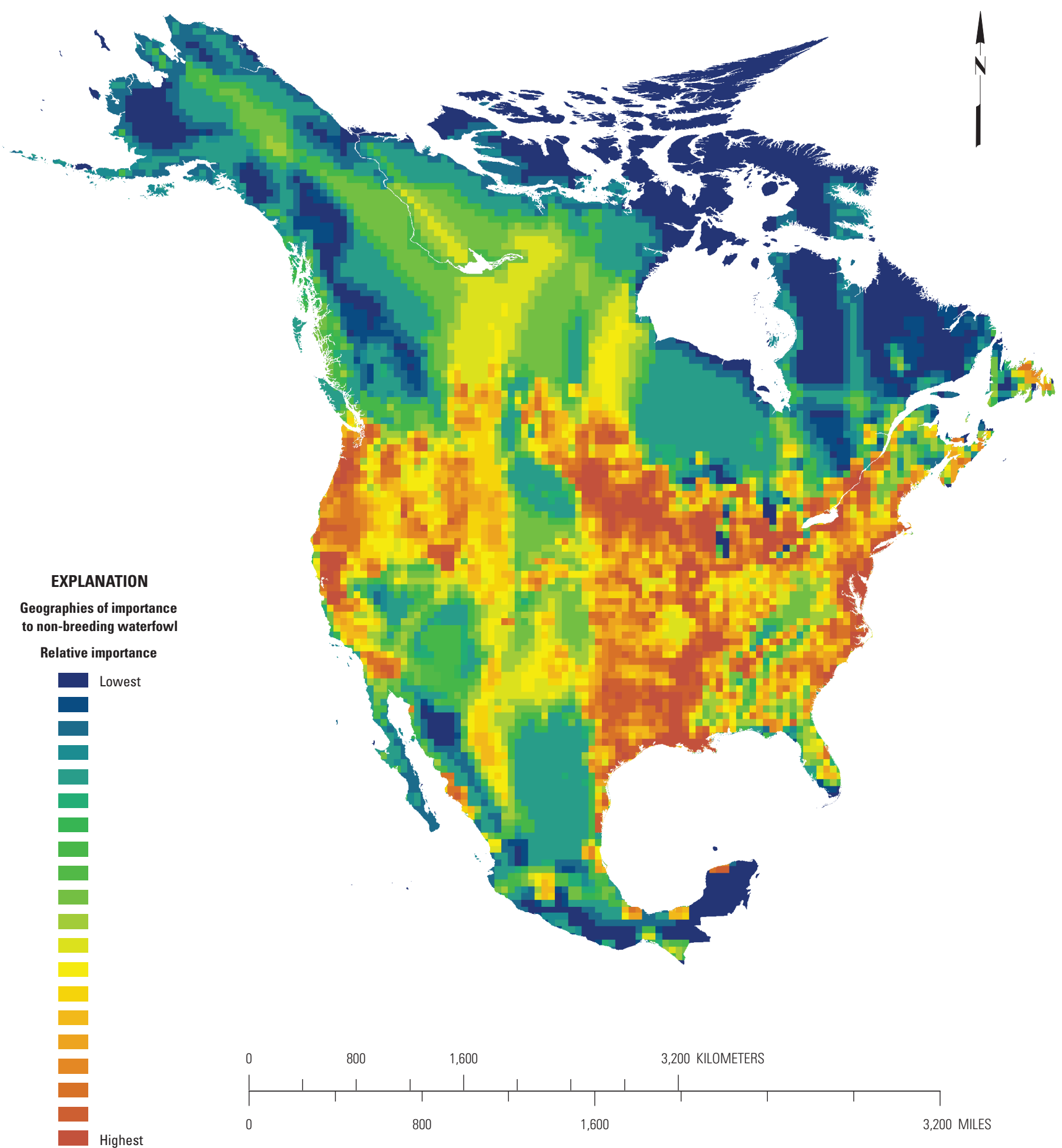

Figure 5. Relative importance of geographies to waterfowl during the non-breeding period. The spatial product is an aggregation of 10 biological objectives (non-breeding mallard, American black duck, northern pintail, scaup spp., wood duck, dabbling ground nester guild, diving overwater nester guild, diving cavity nester guild, diving ground nester guild, and geese and swans), each with equal weight of 0.1 . 


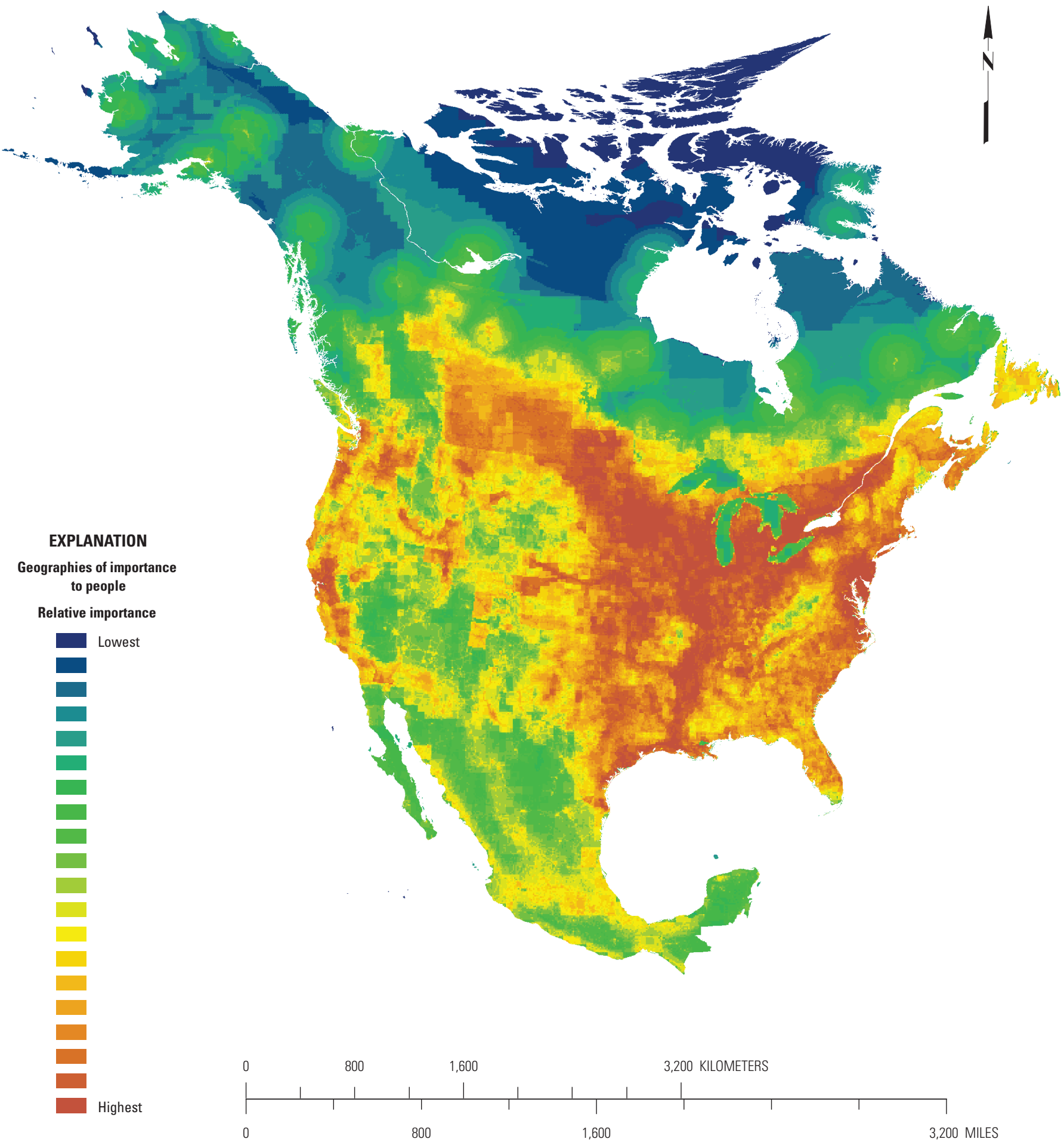

Figure 6. Relative importance of geographies to waterfowl conservation supporters. The spatial product is an aggregation of five social objectives (distance to urban centers, waterfowl diversity, obligate wetland bird diversity, hunter days afield, and watershed impairment status; some of the objectives are a composite of several sub-objectives), each with equal weight of 0.2 . 


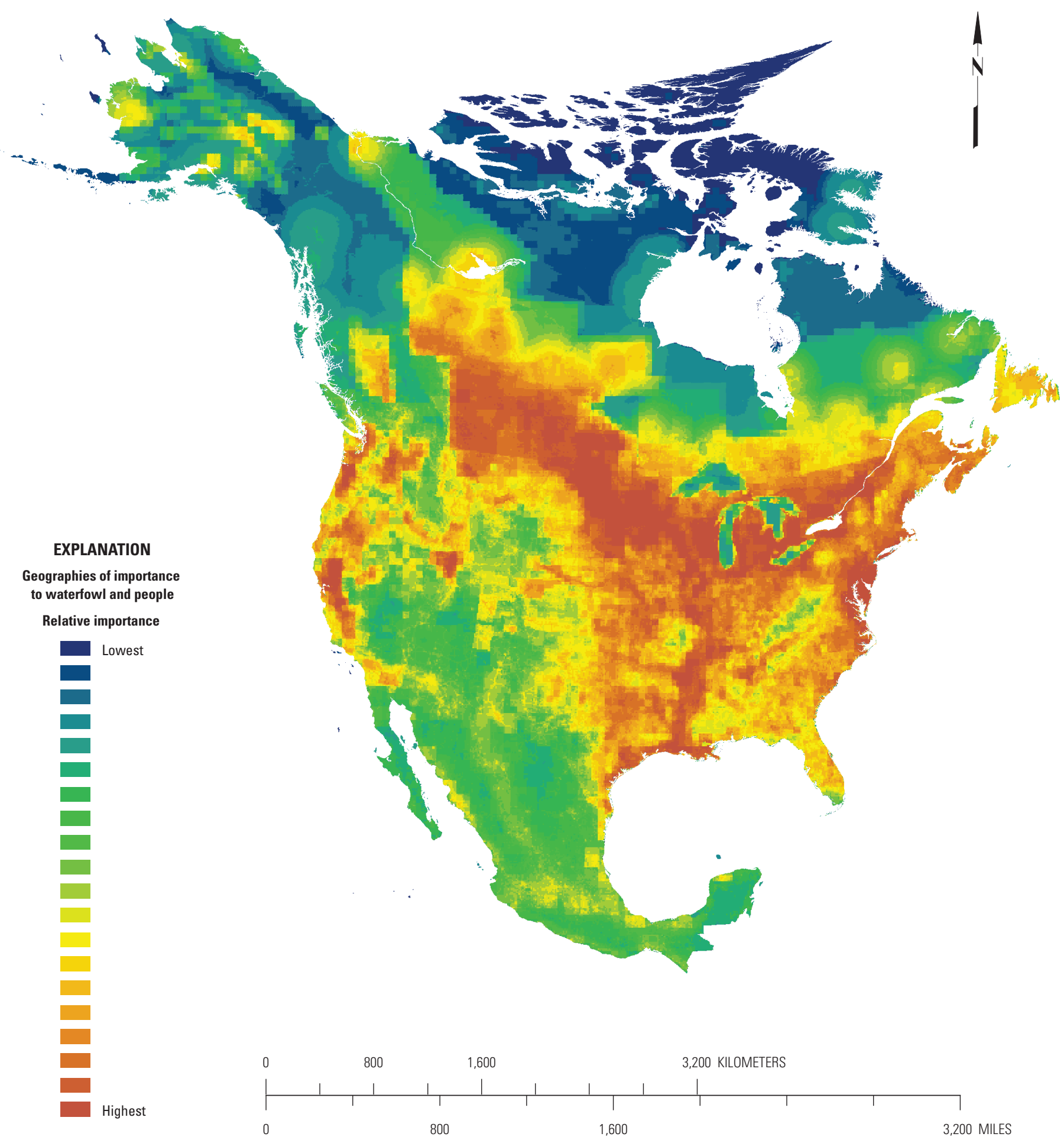

Figure 7. Relative importance of geographies to waterfowl during the breeding and non-breeding periods and to waterfowl habitat conservation supporters. The spatial product is an aggregation of eight biological and social objectives (breeding duck densities, non-breeding duck use days densities, breeding and non-breeding geese and swans, distance to urban centers, waterfowl diversity, obligate wetland bird diversity, hunter days afield, and watershed impairment status; some of the objectives are a composite of several sub-objectives). Biological objectives each have an equal value of 0.25 divided by the number of sub-objectives (that is, nine species/ guilds), and social objectives each have a cumulative weight of 0.5 divided by the number of sub-objectives. 


\section{Discussion}

The demand for spatially explicit conservation tools that integrate multiple biological and social objectives has been at the forefront of North American waterfowl conservation in recent years. In this study, the SDM framework was used to develop a spatial value model, which will aid waterfowl habitat conservation decisions. The study defined the decision problem, identified relevant biological and social objectives at the continental scale, defined performance measures and utility functions, and employed the multi-criteria linear value modeling process to develop several spatial products. The SDM framework offers a science-based, transparent, and defensible approach for evaluating decisions about the allocation of resources for waterfowl habitat conservation in landscapes that best achieve priority objectives for waterfowl and people.

The spatial value models represent the collective judgments of the PLC regarding goals and objectives of 2012 NAWMP. Comparisons with recently developed NAWMP maps (Soulliere and others, 2012) and related population-distribution literature indicate several similarities in priority landscape identification. The Prairie Pothole Region is one of the most productive duck habitats in the world (Batt and others, 1989). The Canadian Western Boreal Forest and Alaska are high priority breeding waterfowl areas that generally attract a low density of birds, but the size of the region (nearly 0.61 billion hectares) supports $12-14$ million ducks during the breeding season (Smith, 1995; Slattery and others, 2011). Breeding duck densities were relatively high in the Upper Mississippi River and Great Lakes region, which is also important during migration and winter periods, accounting for an estimated 1.6 billion annual waterfowl use days (Soulliere and others, 2017).

Areas consistently identified as important to wintering waterfowl include the California Central Valley, which supports 60 percent of the Pacific Flyway's wintering waterfowl (Fleskes and others, 2013; Miller and others, 2010) and nearly 40 percent of the continental wintering northern pintail population (Ballard and others, 2004). The Mississippi Alluvial Valley is a key wintering and migration area for midcontinent waterfowl and supports peak populations of 7-8 million ducks and geese (Kross and others, 2008; Feaga, 2014; Davis and others, 2014). Finally, the United States western gulf coast supports approximately 14 million wintering ducks and 2 million geese (Chabreck and others, 1989; Ballard and others, 2004; Bolduc and Afton 2004; Davis and others, 2014).

All of the above regions have been recognized by U.S. Fish and Wildlife Service, Ducks Unlimited, and the 2012 NAWMP as regions of high conservation priority. Likewise, the three biologically focused spatial products in this report (figs. 3-5) identify these areas as geographies of greatest importance to breeding and non-breeding waterfowl, supporting previous conclusions that they are priority areas for resource allocation. Compared to the 2012 NAWMP map (fig. 2), these three spatial value models identified expanded areas of the Midwest and Eastern United States as areas of importance to waterfowl, especially during the non-breeding period (fig. 5). By developing spatial value models that are season specific (breeding versus non-breeding), we were able to depict additional non-breeding areas that were not identified when breeding and non-breeding objectives were considered together. In addition, although most of these areas had been documented as important to waterfowl (NAWMP, 2012), previous efforts to identify priority geographies were often based on expert opinion, inconsistent regional abundance surveys, and local empirical studies. Notwithstanding known deficiencies in survey data discussed below, the biological spatial value models presented herein are based on continentally consistent and current (2001-15) data; map products are further supported by the collective knowledge of the PLC regarding waterfowl abundance and distribution.

It was no surprise that geographies heavily populated with people (that is, Atlantic Coast of United States, Upper Midwest/Great Lakes region, Pacific Coast of United States, Mississippi Alluvial Valley, United States Gulf Coast, and the southern border of Canada) were identified as areas most important for achieving social objectives. Although Mexico was not identified as an area of greatest importance, based on social objectives, this result was likely due to data limitations, as discussed in section "Benefits, Limitations and the Future" of this report. When biological and social objectives were integrated in the spatial value model, there was no significant shift in geographies of greatest importance, rather those regions most important biologically to waterfowl generally expanded to capture social landscape attributes.

We noted some differences between previously defined geographies of importance (NAWMP, 2012) and the three spatial products related to biological objectives presented here. For example, the gulf coast of Mexico, Lagos y Lagunas Centro/Humedales del Valle de Mexico, Tierra Altas Notre, Costa del Pacifico, and Baja California were not identified as geographies of continental importance to waterfowl in spatial value models presented herein. The most likely explanation for this discrepancy is lack of waterfowl abundance data. The spatial model relies on survey data, and adequate breeding and non-breeding population abundance data from all regions are required to assess relative biological importance. Other geographies identified in the past for their continental importance (NAWMP, 2012) but not captured using the spatial value model include Hudson and James Bays, the high Arctic regions, Platte River and Rainwater Basin, Central Kansas Marshes, and the Playa Wetlands Region. Reasons for the lower relative importance of geographies depicted through this effort are (1) lower breeding species diversity in some geographies (for example, Hudson and James Bays were mostly critical for breeding Canada geese), or (2) geographies were determined to be critical only during a relatively short duration of the non-breeding period (that is, migration staging on the Platte River and Rainwater Basin, Central Kansas Marshes, and the Playa Wetlands Region). Exclusion of potentially important non-breeding areas may reflect a limitation in the DUD calculation used because remote regions with limited 
waterfowl harvest and or bird watching activity may be under-represented in DUD calculations (see DUD methodology, Brasher and others, Ducks Unlimited, written commun., 2018).

\section{Benefits, Limitations, and the Future}

What is the quantity and quality of habitat needed to support abundant waterfowl populations and ecosystem services? The answer has often depended on the availability of funding and policy-driven conservation targets. However, Svancara and others (2005) illustrate the variance in the answer to this question when conservation decisions and initiatives are approached from science-based targets as opposed to policybased targets. With the development of many conservation planning tools and the significant increase in conservation planning activity around the world over the last decade, we no longer need to rely on policy-driven targets. Instead, conservation targets need to be informed by conservation planning processes that are based simultaneously on the biological needs of species, communities, and ecosystems (Svancara and others, 2005). NAWMP (2012) population abundance estimates are based on the best available data and historical knowledge of population dynamics. Therefore, conservation planning tools designed to aid waterfowl habitat conservation planning also need to be based on high quality empirical data, clearly outlined assumptions, and acknowledgments of uncertainty and risk. The performance measures defined for each biological and social objective in this study are based on empirical data from a contemporary period (2001-15). Predictive modeling and assumption-driven spatial conservation planning can be used when empirical data are limited (Guisan and Zimmermann, 2000; Millspaugh and Thompson, 2011). However, decisions that are supported by sound science and data representing known conditions generally increase confidence in the success of conservation initiatives.

George Box made famous the statement, "All models are wrong, some are useful," in 1976 (Box, 1979). Even if the best scientific information is used in the model building process and it is based on proven ecological and biological concepts, there is an ever-present degree of uncertainty and risk. Uncertainties and risks stem from gaps in knowledge and assumptions about species-habitat associations, human behavior and values, and simple mathematical variation (Nichols and others, 1995). Conservation planners often recognize the limitations of models and make decisions based on support from the models, not on straightforward results of models. Therefore, it is crucial for any model to be completely transparent in its development. This study emphasized transparency of spatial value model development for several reasons. Transparency and clear methodology increase confidence in the model by decision makers, encourage challenges of assumptions and valuation of objectives and preferences, illuminate gaps in data and knowledge, and provide areas for refinement in the future. We aimed for transparency by providing all supplemental information for development of spatial value models and stakeholder input in the appendixes and Supplemental Information to this report.

Transparency and documentation of the model development process also ensures repeatability. The several spatially explicit conservation planning tools developed by NAWMP $(1986,1994,1998,2004,2012)$ demonstrate the change associated with each iteration. Only part of NAWMP planning was data driven because the policy and planning context for the NAWMP differed from one iteration to the next. However, as more data become available and as modeling and mapping software become more sophisticated, data-driven changes can be incorporated into the spatial value model to reflect the shifting baseline. Additionally, repeatability and refinement of the spatial value model make this an adaptive tool, which can serve to inform progress towards meeting NAWMP biological and social objectives (Lyons and others, 2008; Allen and others, 2011). This process needs to include the testing of assumptions about species-habitat associations and their interactions with social objectives, ultimately resulting in management and conservation decisions that are defensible (McLain and Lee, 1996; Salafsky and others, 2001).

To some extent, flexibility is an important aspect of conservation planning tools. Factors that can affect the identification of priority geographies will inevitably affect targetsetting and resource allocation. The PLC identified biological and social objectives that were deemed to be important to the waterfowl management community; however, there may be other relevant objectives at regional scales which were not included. For example, regional objectives may include benefits of waterfowl habitat conservation to aquifer recharge, as is the case in the Playa Lakes region (Bolen and others, 1989; Haukos and Smith, 1992; Smith and others, 2011), or the reduction in loss of coastal wetlands resulting from sea-level rise and saltwater intrusion, as in the Gulf Coast (Boesch and others, 1994; Brasher and others, 2012). Moreover, continental objectives identified by the PLC may not align with the objectives of decision makers working at smaller scales. For example, the density and abundance of breeding mottled ducks did not strongly affect the identification of important areas at the continental scale, but clearly, abundance objectives for this species are relevant to the Gulf Coast region. Likewise, the abundance of breeding American black duck was used by the PLC as a priority, but this objective is most relevant in the northeastern United States and Canada. Flexibility to include or exclude any number of objectives when identifying geographies of priority is built into the spatial value model. Additionally, the PLC defined utility functions and objective weights at the continental scale. It should be noted that preference and weight setting is not an exact science because subjective valuation is involved (Keeney and Raiffa, 1993; Gregory and others, 2012). In this report, we present spatial products using an equal weight distribution among objectives; however, flexibility for varying weights is built into the spatial value model. Finally, flexibility offers decision makers a scalable approach 
to identifying geographies of importance. Regional decision makers have the option to vary the number of objectives and the weights they assign to those objectives to develop spatial products that are specific to their region. However, as it is currently presented, this process involves significant time and staff input. A tool that automates this process through a user interface and allows for rapid generation of regional spatial value models with varying objectives and weights is being developed as of 2019 (Krainyk and others, U.S. Geological Survey, written commun., 2019); this tool will allow scenario playing to inform alternative decisions.

The function of the spatial value model is to serve as a tool in aiding resource allocation decisions; it is not a decision-making tool. For this reason, it is critical to state the limitations and data gaps of the model. This spatial value model is based on assumptions about the biological response of waterfowl to habitat conservation initiatives, the behavioral responses of current and potential conservation supporters, and the uncertainty in future conditions. For example, it is assumed that focusing waterfowl habitat initiatives in areas close to urban centers and where the hunting community is active will encourage waterfowl hunter recruitment, retention, and reactivation. However, a persistent downward trend in waterfowl hunter numbers at the continental scale may reflect a societal shift in values (Vrtiska and others, 2013) rather than a result of limited hunting opportunity. These assumptions can be tested through conservation implementation, monitoring, and assessment of success towards specific goals. Monitoring is an integral component of conservation planning (Lyons and others, 2008; Allen and others, 2011) and serves to inform model refinement in the future.

An important limitation of any model is the uncertainty of the future. Although some uncertainty can be resolved with better predictive models, such as predicted rates of wetland loss, urban expansion, and sea level rise (Nicholls, 2004; Traill and others, 2011; Seto and others, 2012), there are other uncertainties that cannot be resolved. These include, for example, changes in policy or funding as a result of socioeconomic shifts, unpredictable catastrophic events (that is, wildfires, hurricanes), and population dynamics events such as disease or massive die offs owing to contamination. It is vital for decision makers to recognize that uncertainty always exists. However, with better predictive modeling, future refinements of the spatial value model can incorporate parametric uncertainty (for example, probability distributions associated with each attribute), which would then be used to generate expected values in response to management alternatives (Conroy and others, 2011; Gregory and others, 2012). Going hand-in-hand with uncertainty is risk. The degree of model uncertainty can become a good predictor of the decision maker's attitude towards risk. There are three types of risk attitudes-(1) riskaverse decision makers (that is, utility function is concave), (2) risk-prone decision makers (that is, utility function is convex), and (3) risk-neutral decision makers (that is, utility function is a straight line; Gregory and others, 2012). In this study, decision makers were risk averse for most of the biological and social objectives. Only a few objectives (that is, breeding and non-breeding geese and swans, obligate wetland bird diversity) revealed a change from risk-prone to risk-averse attitude, with the utility functions resembling S-shaped curves. Since the utility functions in this study were based on the collective input from members of the geographically diverse PLC, they do not necessarily represent the risk attitudes of decision makers at regional scales. The ability to change utility functions (that is, the risk attitude) for any of the social and regional objectives is included in the development of this model.

Uncertainty, in part, stems from data limitations. The spatial value model described herein has data limitations that we acknowledge and document for transparency. One of the major data limitations is national data related to some objectives (for example, breeding and non-breeding waterfowl and hunter days afield) in Mexico. This limitation produces spatial products that depict Mexico as lower priority for breeding and non-breeding waterfowl and some social objectives. However, these findings may not depict true conditions. The gulf coast of Mexico is known to be an important area for non-breeding waterfowl (Chabreck and others, 1989; Batzer and Baldwin, 2012; NAWMP, 2012), and the Baja California and Baja California Sur regions are known as important non-breeding areas for Branta bernicla nigricans (Pacific black brant; Mallek and others, 2010; Baldassarre, 2014). We caution the interpretation of spatial products that depict continental geographies of importance when using the spatial value model to inform waterfowl habitat initiatives in Mexico. As an alternative, waterfowl habitat conservation initiatives in Mexico could incorporate only the spatial extent associated with Mexico's national boundaries. Although data limitations will not be addressed using this alternative, geographies of potential importance in the country will not be directly compared to other regions in North America with relatively abundant monitoring data.

Finally, we caution the application of continental spatial products in this report for regional (smaller scale) waterfowl habitat conservation decisions. This concern stems from the inherent variation in regional objectives, valuation of weights (to be established by relevant stakeholders), and risk attitude of decision makers. This limitation is addressed in Krainyk and others (U.S. Geological Survey, written commun., 2019) with a Conservation Planning Tool that allows for flexibility in varying scales, objectives, and weights, using an interface coded in Microsoft Excel. We acknowledge that the methodology described herein may be used to achieve the same results, but extensive ArcGIS expertise and processing time are needed. 


\section{Summary}

A spatial value model was developed to assist the North American waterfowl management community (North American Waterfowl Management Plan [NAWMP], 2012) as a spatial conservation planning tool that is flexible, transparent, scalable, and repeatable. The model can be used to aid in resource allocation decisions regarding waterfowl habitat conservation, where social and biological objectives are integrated to better achieve the three goals of the NAWMP (2012) at multiple scales. The goals are (1) maintain abundant and resilient waterfowl populations to support hunting and other uses without impairing habitat; (2) maintain wetlands and related habitats sufficient to sustain waterfowl populations at desired levels, while providing places to recreate and ecological goods and services that benefit society; and (3) encourage an increase in the numbers of waterfowl hunters, other conservationists, and citizens who enjoy and actively support waterfowl and wetland conservation. Products of the model are, for example, maps showing the relative importance of geographies to waterfowl during the breeding and non-breeding period, during the breeding period, and during the non-breeding period. Maps also were produced showing the relative importance of geographies to waterfowl conservation supporters, waterfowl during breeding and non-breeding periods, and waterfowl habitat conservation supporters. Direct application of these continental spatial products, with their general objectives and fixed equal weights, to regional and smaller-scale decisions needs to be done with caution. In this regard, the model is a tool that provides a starting point for discussions about values and associated weights that depend on specific decision contexts.

Several options are discussed for future refinement of the spatial value model to ensure its acceptance by NAWMP and the waterfowl habitat conservation community.

1. Incorporate data on biological and social objectives as new information becomes available to address data limitations and decrease uncertainty.

2. Regional waterfowl habitat conservation decisions need not necessarily be based on the spatial products created at the continental scale. The same attributes used at the continental scale, however, might be appropriate and applicable at regional or local scales.

3. Results of waterfowl habitat conservation decisions, based on the spatial products described herein (and smaller-scale versions), need to be monitored to test assumptions and reduce knowledge gaps related to species-habitat interactions and human behavior.

4. Regional decision makers are encouraged to take the next step by developing regional spatial products, based on the objectives and spatial data available as supplemental material to this report. Spatial data are available in a companion data release (Krainyk, 2019, available at https://doi.org/10.5066/P9L7J5U4).
This report addresses many of the concerns outlined by Soulliere and others (2012). Limited financial resources for habitat conservation creates a need for tools that prioritize areas for investment and address decisions with integrated biological and social objectives. This is the first continental scale effort to develop a spatial value model with multiple objectives. Ongoing discussions with the NAWMP community focus on the logistics of making this conservation planning tool available to decision makers at different scales and on the development of Geographies of Greatest Continental Significance to Waterfowl and Waterfowl Habitat Conservation Supporters spatial product utilizing region-specific objectives, risk attitudes, and weight valuation.

\section{References Cited}

Allen, C.R., Fontaine, J.J., Pope, K.L., and Garmestani, A.S., 2011, Adaptive management for a turbulent future: Journal of Environmental Management, v. 92, no. 5, 1339-1345.

Anderson, M.G., and Padding, P.I., 2015, The North American approach to waterfowl management: synergy of hunting and habitat conservation: International Journal of Environmental Studies, v. 72, no. 5, p. 810-829.

Baldassarre, G.A., 2014, Ducks, geese, and swans of North America: Baltimore, Md., Johns Hopkins University Press, $1027 \mathrm{p}$.

Baldassarre, G.A., and Bolen, E.G., 2006, Waterfowl ecology and management (2d ed.): Malabar, Fla., Krieger, 580 p.

Balk, D.L., Deichmann, U., Yetman, G., Pozzi, F., Hay, S.I., and Nelson, A., 2006, Determining global population distribution: Methods, applications and data: Advances in Parasitology, v. 62, p. 119-156.

Ballard, B.M., Thompson, J.E., Petrie, M.J., Checkett, M., and Hewitt, D.G., 2004, Diet and nutrition of northern pintails wintering along the southern coast of Texas: Journal of Wildlife Management, v. 68, no. 2, p. 371-382.

Batt, B.D.J, ed., 1997, Arctic ecosystems in peril: report of the Arctic Goose Habitat Working Group: Arctic Goose Joint Venture Special Publication, U.S. Fish and Wildlife Service, Washington, D.C., USA, and Canadian Wildlife Service, Ottawa, Ontario, Canada.

Batt, B.D.J., Anderson, M.G., Anderson, C.D., and Caswell, F.D., 1989, The use of prairie potholes by North American ducks, in Van der Valk, A., ed., Northern prairie wetlands: Ames, Ia, Iowa State University Press, p. 204-227.

Batzer, D.P., and Baldwin, A.H., 2012, Wetland habitats of North America: Ecology and conservation concerns: Berkley, Calif., University of California Press, p. 408. 
Bell, D.E., 2007, Utility and risk preference, in Edwards, W., Miles, R.F., and von Winterfeldt, D., eds., Advances in decision analysis: from foundations to applications: New York, Cambridge University Press, p. 221-231.

Boesch, D.F., Josselyn, M.N., Mehta, A.J., Morris, J.T., Nuttle, W.K., Simenstad, C.A., and Swift, D.J.P., 1994, Scientific assessment of coastal wetland loss, restoration and management in Louisiana: Journal of Coastal Research, Special Issue No. 20, p. 1-103.

Bolduc, F. and Afton, A.D., 2004, Relationships between wintering waterbirds and invertebrates, sediments and hydrology of coastal marsh ponds: Waterbirds, v. 27, no. 3, p. 333-341.

Bolen, E.G., Smith, L.M., and Schramm, Jr., H.L., 1989, Playa Lakes - Prairie Wetlands of the Southern High Plains: BioScience, v. 39, no. 9, p. 615-623.

Box, G.E.P., 1979, Robustness in scientific modeling, in Laurer, R.L. and Wilkinson, G.N., eds., Robustness in statistics: New York, Academic Press, p. 201-236.

Brasher, M.G., James, J.D., and Wilson, B.C., 2012, Gulf Coast Joint Venture priority waterfowl science needs: Lafayette, La., Gulf Coast Joint Venture, 54 p., accessed May 20, 2018, at http://www.gcjv.org/docs/GCJV\%20 Waterfowl $\% 20$ Science $\% 20$ Needs $\% 20$ Plan $\% 20-\% 20$ May\%202012.pdf.

Brown, K., Adger, W.N., Tompkins, E., Bacon, P., Shim, D., and Young, K., 2001, Trade-off analysis of marine protected area management: Ecological Economics, v. 37, p. 417-434.

Capmourteres, V., and Anand, M., 2016, Conservation valuea review of the concept and its quantification: Ecosphere, v. 7 , no. 10 , p. 1-19.

Chabreck, R.H., Joanen, T., and Paulus, S.L., 1989, Southern coastal marshes and lakes, in Smith, L.M., Pederson, R.L., and Kaminski, R.M., eds., Habitat management for migrating and wintering waterfowl in North America: Lubbock, Tex., Texas Tech University Press, p. 249-277.

Clark, R.G., Anderson, M.G., Bartuszevige, A., Brasher, M., Humburg, D., and Vest, J., 2015, Towards integrating multiple Joint-Venture scale objectives to achieve NAWMP goals - Lessons learned: Memphis, Tenn., Workshop report, 46 p., accessed June 12, 2018, at https://nawmp. org/sites/default/files/2018-02/FINAL\%20Integration\%20 Workshop\%20Report\%20-\%20Lessons\%20Learned $\% 20$ about $\% 20$ Integration $\% 20$ Steps $\% 20$ for $\% 20$ People $\% 20$ and $\% 20$ Habitat.pdf.

Clemen, R.T., 1996, Making hard decisions-An introduction to decision analysis ( $2 \mathrm{~d}$ ed.): Belmont, Calif., Duxbury Press, 664 p.
Conroy, M.J., and Peterson, J.T., 2013, Decision making in natural resource management-A structured, adaptive approach: West Sussex, UK,Wiley-Blackwell, p. 474.

Conroy, M.J., Runge, M.C., Nichols, J.D., Stodola, K.W., and Cooper, R.J., 2011, Conservation in the face of climate change-The roles of alternative models, monitoring, and adaptation in confronting and reducing uncertainty: Biological Conservation, v. 144, no. 4, p. 1204-1213.

Cook, C.N., Inayatullah, S., Burgman, M.A., Sutherland, W.J., and Wintle, B.A., 2014, Strategic foresight-how planning for the unpredictable can improve environmental decisionmaking: Trends in Ecology and Evolution, v. 29, no. 9, p. 531-541.

Davis, J.B., Guillemain, M., Kaminski, R.M., Arzel, C., Eadie, J.M., and Rees, E.C., 2014, Habitat and resource use by waterfowl in the northern hemisphere in autumn and winter: Wildfowl Special Issue 4, p. 17-69.

de Groot, R.S., Alkemade, R., Braat, L., Hein, L., and Willemen, L., 2010, Challenges in integrating the concept of ecosystem services and values in landscape planning, management and decision making: Ecological Complexity, v. 7 , no. 3, p. 260-272.

Decker, D.J., Brown, T.L., and Siemer, W.F., 2012, Human dimensions of wildlife management in North America: Bethesda, Md., The Wildlife Society, Johns Hopkins University Press, $447 \mathrm{p}$.

Devers, P.K., Roberts, A.J., Knoche, S., Padding, P.I., and Raftovich, R., 2017, Incorporating human dimension objectives into waterfowl habitat planning and delivery: Wildlife Society Bulletin, v. 41, no. 3, p. 405-415.

Dooley, J.L., Sanders, T.A., and Doherty, Jr., P.F., 2010, Mallard response to experimental walk-in and shooting disturbance: Journal of Wildlife Management, v. 74, no. 8, p. 1815-1824.

Dyer, J.S., 2005, MAUT - Multiattribute utility theory, in Figueira, J., Greco, A., Ehrgott, M., eds., Multiple criteria decision analysis: New York, Springer Science + Business Media, Inc., p. 265-295.

Edwards, W., Miles, R.F., and von Winterfeldt, D., 2007, Advances in decision analysis-From foundations to applications: New York, Cambridge University Press, 623 p.

Egoh, B., Rouget, M., Reyers, B., Knight, A., Cowling, R.M., Van Jaarsveld, A.S., and Welz, A., 2007, Integrating ecosystem services into conservation assessments-A review: Ecological Economics, v. 63, no. 4, p. 714-21.

ESRI (Environmental Systems Resource Institute), 2011, ArcMap 10.1: Redlands, Calif., ESRI. 
Evans, K.L., van Rensburg, B.J., Gaston, K.J., and Chown, S.L., 2006, People, species richness and human population growth: Global Ecology and Biogeography, v. 15, no. 6, p. 625-636.

Feaga, J.S., 2014, Winter waterbird use and food resources of aquaculture lands in Mississippi: Master's Thesis, Mississippi State, Miss., Mississippi State University, 73 p.

Fleming, K.K., Brasher, M.G., Humburg, D.D., Petrie, M.J., and Soulliere, G.J., 2017, Derivation of regional nonbreeding duck population abundance objectives to inform regional conservation planning: North American Waterfowl Management Plan Science Support Team Technical Report No. 2017-01, 32 p., accessed August 23, 2018, at https:// www.fws.gov/migratorybirds/pdf/management/NAWMP/ DerivationofNon-breedingDuckPopulationAbundanceObjectives.pdf.

Fleskes, J.P., Skalos, D.A., and Farinha, M.A., 2013, Changes in types and area of postharvest flooded fields available to waterbirds in Tulare Basin, California: Journal of Fish and Wildlife Management, v. 4, no. 2, p. 351-361.

Folke, C., Hahn, T., Olsson, P., and Norberg, J., 2005, Adaptive governance of social-ecological systems: Annual Review of Environment and Resources, v. 30, p. 441-473.

Gregory, R., Failing, L., Harstone, M., Long, G., McDaniels, T., and Ohlson, D., 2012, Structured decision making: a practical guide to environmental management choices (1st ed.): West Sussex, UK, Wiley-Blackwell, 312 p.

Guisan, A., and Zimmermann, N.E., 2000, Predictive habitat distribution models in ecology: Ecological Modeling, v. 135 , no. $2-3$, p. $147-186$.

Hammond, J.S., Keeney, R.L., and Raiffa, H., 1999, Smart choices-A practical guide to making better life decisions: Boston, Mass., Harvard Business School Press, 256 p.

Haukos, D.A., and Smith, L.M., 1992, Ecology of Playa Lakes 13.3.7.-Waterfowl Management Handbook. 19: U.S. Department of Interior, $7 \mathrm{p}$.

Holling, C.S., 1978, Adaptive environmental assessment and management: New York, Wiley and Sons, 402 p.

Imhoff, M.L., Bounoua, L., Ricketts, T., Loucks, C., Harriss, R., and Lawrence, W.T., 2004, Global patterns in human consumption of net primary production: Nature, v. 429, p. $870-873$.

Keeney, R.L., 1992, Value-focused thinking: a path to creative decision making: Cambridge, Mass., Harvard University Press, $432 \mathrm{p}$.

Keeney, R.L., and Gregory, R.S., 2005, Selecting attributes to measure the achievement of objectives: Operations Research, v. 53, no. 1, p. 1-11.
Keeney, R.L. and Raiffa, H., 1993, Decisions with multiple objectives: Cambridge, Mass., Cambridge University Press, $592 \mathrm{p}$.

Kerbes, R.H., Meeres, K.M., and Alisauskas, R.T., 2014, Surveys of nesting lesser snow geese and Ross's geese in Arctic Canada, 2002-09: Arctic Goose Joint Venture Special Publication, U.S. Fish and Wildlife Service, Washington, D.C. and Canadian Wildlife Service, Ottawa, Ontario.

Kirkwood, C.W., 1997, Strategic decision making: multiobjective decision analysis with spreadsheets: Belmont, Mass., Duxbury Press, 345 p.

Krainyk, A., 2019, Spatial Integration of Biological and Social Objectives to Identify Priority Landscapes for Waterfowl Habitat Conservation-Spatial Data Release: U.S. Geological Survey data release, https://doi.org/10.5066/P9L7J5U4.

Krementz, D.G., Conroy, M.J., Hines, J.E., and Percival, H.F., 1988, The effects of hunting on survival rates of American Black Ducks: Journal of Wildlife Management, v. 52, no. 2, p. 214-226.

Kross, J.P., Kaminski, R.M., Reinecke, K.J., and Pearse, A.P., 2008, Conserving waste rice for wintering waterfowl in the Mississippi Alluvial Valley: Journal of Wildlife Management, v. 72 , no. 6 , p. 1383-1387.

Legagneux, P., Blaize, C., Latraube, F., Gautier, J., and Bretagnolle, V., 2009, Variation in home-range size and movements of wintering dabbling ducks: Journal of Ornithology, v. 150 , no. 1 , p. $183-193$.

Lyons, J.E., Runge, M.C., Laskowski, H.P., and Kendall, W.L., 2008, Monitoring in the context of structured decision-making and adaptive management: Journal of Wildlife Management, v. 72 , no. 8, p. 1683-1692.

Mallek, E., Wortham, J., and Eldridge, W., 2010, Winter waterfowl survey Mexico west coast and Baja California, January 2010-Annual report: Fairbanks, Alaska, U.S. Fish and Wildlife Service, 13 p., accessed October 11, 2017, at https://www.fws.gov/alaska/mbsp/mbm/waterfowl/surveys/ pdf/mexico_brant.pdf.

Margules, C.R., and Pressey, R.L., 2000, Systematic conservation planning: Nature, v. 405, p. 243-253.

Martin, J., Runge, M.C., Nichols, J.D., Lubow, B.C., and Kendall, W.L., 2009, Structured decision making as a conceptual framework to identify thresholds for conservation and management: Ecological Application, v. 19, no. 5, p. 1079-1090.

McLain, R.J., and Lee, R.G., 1996, Adaptive managementPromises and pitfalls: Environmental Management, v. 20, no. 4, p. 437-448. 
Miller, M.R., Garr, J.D., and Coates, P.S., 2010, Changes in the status of harvested rice fields in the Sacramento Valley, California - implications for wintering waterfowl: Wetlands, v. 30, no. 5, p. 939-947.

Millspaugh, J.J., and Thompson, F.R., 2011, Models for planning wildlife conservation in large landscapes: Boston, Mass., Elsevier/Academic Press, 720 p.

Nelson, E., Mendoza, G., Regetz, J., Polasky, S., Tallis, H., Cameron, D.R., Chan, K.M., Daily, G.C., Goldstein, J., Kareiva, P.M., Lonsdorf, E., Naidoo, R., Ricketts, T.H., and Shaw, M.R., 2009, Modeling multiple ecosystem service, biodiversity conservation, commodity production, and tradeoffs at landscape scales: Frontiers in Ecology and the Environment, v. 7, no. 1, p. 4-11.

Nichols, J.D., Johnson, F.A., Williams, B.K., 1995, Managing North American waterfowl in the face of uncertainty: Annual Review of Ecology and Systematics, v. 26, p. 177-199.

Nicholls, R.J., 2004, Coastal flooding and wetland loss in the 21st century - changes under the SRES climate and socioeconomic scenarios: Global Environmental Change, v. 14, no.1, p. 69-86.

North American Bird Conservation Initiative, U.S. Committee, 2011, The state of the birds 2011 Report on Public Lands and Waters: Washington, D.C., U.S. Department of Interior, 48 p., accessed April 20, 2018, at http://www.stateofthebirds.org/2011/State\%20of\%20the\%20Birds\%202011.pdf.

North American Waterfowl Management Plan (NAWMP), 1986, North American Waterfowl Management Plan-A strategy for cooperation: U.S. Department of Interior, Fish and Wildlife Service, and Environment Canada, Canadian Wildlife Service, 26 p., accessed March 12, 2017, as https:// nawmp.org/sites/default/files/2018-01/1986\%20OriginalNAWMP.pdf.

North American Waterfowl Management Plan (NAWMP), 1994, North American Waterfowl Management PlanExpanding the Commitment: U.S. Department of Interior, Fish and Wildlife Service, and Environment Canada, Canadian Wildlife Service, 47 p., accessed March 15, 2017, at https://nawmp.org/sites/default/files/2018-01/1994\%20 NAWMP\%20Update.pdf.

North American Waterfowl Management Plan (NAWMP), 1998, North American Waterfowl Management PlanExpanding the Vision: U.S. Department of Interior, Fish and Wildlife Service, and Environment Canada, Canadian Wildlife Service, Canadian Wildlife Service, U.S. Fish and Wildlife Service, Secretaria de Medio Amiente y Recursos Naturales, 43 p., accessed March 23, 2017, at https://nawmp.org/sites/default/files/2018-01/1998\%20 NAWMP\%20Update.pdf.
North American Waterfowl Management Plan (NAWMP), 2004, North American Waterfowl Management Planstrengthening the biological foundation (Implementation Framework): U.S. Department of Interior, Fish and Wildlife Service, and Environment Canada, Canadian Wildlife Service, 120 p., accessed April 2, 2017, at https://nawmp.org/ sites/default/files/2018-01/2004\%20NAWMP-Implementation\%20Framework.pdf.

North American Waterfowl Management Plan (NAWMP), 2012, North American Waterfowl Management Plan 2012 people conserving waterfowl and wetlands: Canadian Wildlife Service, U.S. Fish and Wildlife Service, Secretaria de Medio Amiente y Recursos Naturales, 70 p., accessed April 12, 2017, at https://nawmp.org/sites/default/files/2017-12/ NAWMP-Plan-EN-may23_0.pdf.

North American Waterfowl Management Plan Committee, 2014, Revised objectives_-An addendum to the 2012 North American Waterfowl Management Plan: Washington, D.C., U.S. Fish and Wildlife Service, 10 p., accessed June 5, 2017, at https://www.fws.gov/migratorybirds/pdf/management/NAWMP/2012NAWMPRevisedObjectives.pdf.

Nudds, T.D., 1983, Niche dynamics and organization of waterfowl guilds in variable environments: Ecology, v. 64, no. 2, p. 319-330.

Pullin, A.S., and Knight, T.M., 2001, Effectiveness in conservation practice - pointers from medicine and public health: Conservation Biology, v. 15, no. 1, p. 50-54.

Raftovich, R.V., Chandler, S.C., Fleming, K.K., 2017, Migratory bird hunting activity and harvest during the 2015-16 and 2016-17 hunting seasons. Laurel, Md., U.S. Fish and Wildlife Service, 76 p., accessed June 25, 2017, at https:// www.fws.gov/migratorybirds/pdf/surveys-and-data/HarvestSurveys/MBHActivityHarvest2015-16and2016-17.pdf.

Reynolds, R., Shaffer, T.L., Loesch, C.R., Cox, R.R., 2006, The farm bill and duck production in the prairie pothole region: Increasing benefits: Wildlife Society Bulletin, v. 34, no. 4, p. 963-974.

Romito, A.M., Cochrane, J.F., Eaton, M.J., Runge, M.C., 2015, Problem definition, Module 04, in Runge, M.C., Romito, A.M., Breese, G., Cochrane, J.F., Converse, S.J., Eaton, M.J., Larson, M.A., Lyons, J.E., Smith, D.R., Isham, A.F., eds., Introduction to structured decision making: Shepherdstown, W.V., U.S. Fish and Wildlife Service, National Conservation Training Center.

Sala, O.E., Chapin, III, F.S., Armesto, J.J., Berlow, E., Bloomfield, J., Dirzo, R., Huber-Sanwald, E., Huenneke, L.F., Jackson, R.B., Kinzig, A., Leemans, R., Lodge, D.M., Mooney, H.A., Oesterheld, M., Poff, N.L., Sykes, M.T., Walker, B.H., Walker, M., and Wall, D.H., 2000, Global biodiversity scenarios for the year 2100: Science, v. 287, no. 5459, p. 1770-1774. 
Salafsky, N., Cauley, H., Balachander, G., Cordes, B., Parks, J., Margoluis, C., Bhatt, S., Encarnacion, C., Russell, D., and Margoluis, R., 2001, A systematic test of an enterprise strategy for community-based biodiversity conservation: Conservation Biology, v. 15, no. 6, p. 1585-1595.

Schwartz, M.W., Cook, C.N., Pressey, R.L., Pullin, A.S., Runge, M.C., Salafsky, N., Sutherland, W.J., Williamson, M.A., 2018, Decision support frameworks and tools for conservation: A Journal of the Society for Conservation Biology, v. 11, no. 2, p. 1-12.

Seto, K.C., Güneralp, B., and Hutyra, L.R., 2012, Global forecasts of urban expansion to 2030 and direct impacts on biodiversity and carbon pools: Proceedings of the National Academy of Sciences of the United States of America, v. 109 , no. 40 , p. $16083-16088$.

Simpson, E.H., 1949, Measurement of diversity: Nature, v. $163,688 \mathrm{p}$.

Slattery, S.M., Morissette, J.L., Mack, G., Butterworth, E.W., 2011, Waterfowl conservation planning: Science needs and approaches, in Wells, J.V., Boreal birds of North America: Studies in Avian Biology, v. 41: Berkley, Calif., University of California Press, p. 160.

Smith, G.W., 1995, A critical review of the aerial and ground surveys of breeding waterfowl in North America: Biological Science Report 5: Washington, D.C., U.S. Department of the Interior, National Biological Service, p. 252., accessed September 14, 2017, at http://www.michigandnr.com/ FTP/wildlife/LuukkonenD/Breeding\%20waterfowl $\% 20$ survey\%20project/Smith\%201995.pdf.

Smith, L.M., Haukos, D.A., McMurry, S.T., LaGrange, T., and Willis, D., 2011, Ecosystem services provided by playas in the High Plains: Potential influences of USDA conservation Programs: Ecological Applications, v. 21. no. 3, p. S82-S92.

Soulliere, G.J., and Al-Saffar, M.A., 2017, Targeting conservation for waterfowl and people in the Upper Mississippi River and Great Lakes Joint Venture Region: Upper Mississippi Great Lakes Region Joint Venture, Technical Report No. 2017-1, 16 p.

Soulliere, G.J., Al-Saffar, M.A., Coluccy, J.M., Gates, R.J., Hagy, H.M., Simpson, J.W., Straub, J.N., Pierce, R.L., Eichholz, M.W., and Luukkonen, D.R., 2017, Upper Mississippi River and Great Lakes Region Joint Venture waterfowl habitat conservation strategy_2017 revision: Bloomington, Minn., U.S. Fish and Wildlife Service, 170 p.
Soulliere, G.J., Kahler, K.M., Bowman, T.A., Brasher, M.G., Johnson, M.A., Holbrook, R.S., Petrie, M.J., Vest, J.L., and Slattery, S.M., 2012, Process for developing the 2012 NAMWP map - geographies of greatest continental significance to North American waterfowl: NAWMP Science Support Team, Technical Report No. 2012-01, 27 p.

Sunderland, T., Sunderland-Groves, J., Shanley, P., and Campbell, B., 2009, Bridging the gap: how can information access and exchange between conservation biologists and field practitioners be improved for better conservation outcomes?: Biotropica, v. 41 , no. 5, p. 549-554.

Svancara, L.K., Brannon, R., Scott, J.M., Groves, C.R., Noss, R.F., and Pressey, R.L., 2005, Policy-driven versus evidence-based conservation-A review of political targets and biological needs: BioScience, v. 55, no. 11, p. 989-995.

Traill, L.W., Perhans, K., Lovelock, C.E., Prohaska, A., McFallan, S., Rhodes, J.R., and Wilson, K.A., 2011, Managing for change - wetland transitions under sea-level rise and outcomes for threatened species: Diversity and Distribution, v. 17, no. 6, p. 1225-1233.

U.S. Department of the Interior, Environment Canada, and Environment and Natural Resources Mexico, 2012, North American Waterfowl Management Plan-Action plan, 2012: U.S. Department of the Interior, 62 p., accessed June 21, 2017, at https://nawmp.org/sites/default/files/2018-01/ NAWMP\%20Action\%20Plan\%20Dec\%202012-final\%20 w\%20memo\%20and\%20cover.pdf.

von Winterfeldt, D., and Edwards, W., 2007, Defining a decision analytic structure, in Edwards, W., Miles, R.F., and von Winterfeldt, D., eds., Advances in decision analysis - from foundations to applications: New York, Cambridge University Press, p. 81-103.

Vrtiska, M.P., and Sullivan, S., 2009, Abundance and distribution of lesser snow and Ross's geese in the Rainwater Basin and central Platte River valley of Nebraska: Great Plains Research, v. 19, no. 2, p. 147-155.

Vrtiska, M.P., Gammonley, J.H., Naylor, L.W., and Raedeke, A.H., 2013, Economic and conservation ramifications from the decline of waterfowl hunters: Wildlife Society Bulletin, v. 37 , no. 2 , p. $380-388$.

Walsh, J.C., Dicks, L.V., and Sutherland, W.J., 2015, The effect of scientific evidence on conservation practitioner's management decisions: Conservation Biology, v. 29, no. 1, p. $88-98$. 
Webb, E.B., Smith, L.M., Vrtiska, M.P., and LaGrange, T.G., 2010, Effects of local and landscape variables on wetland bird habitat use during migration through the Rainwater Basin: Journal of Wildlife Management, v. 74, no. 1, p. 109-119.

Whyte, R.J., and Bolen, E.G., 1984, Impact of winter stress on mallard body composition: The Condor, v. 86 , no. 4 , p. 447-482.

Williams, B.K., Koneff, M.D., and Smith, D.A., 1999, Evaluation of waterfowl conservation under the North American Waterfowl Management Plan: Journal of Wildlife Management, v. 63 , no. 2 , p. 417-440.

Wilson, H.M., 2017, Aerial survey of emperor geese and other waterbirds in southwestern Alaska, spring 2016: U.S. Fish and Wildlife Service, 12 p., accessed January 6, 2018, at https://www.fws.gov/alaska/mbsp/mbm/waterfowl/surveys/ pdf/2016_EMGO_Spring_Survey.pdf. 


\section{Appendix 1. Members of the Priority Landscapes Committee}

In 2015, the North American Waterfowl Management Plan Science Support Team, in collaboration with the Interim Integration Committee, formed the Priority Landscapes Committee (PLC) and appointed members from various waterfowl and waterfowl habitat conservation partnerships. Intermittent meetings of the PLC occurred between 2015 and 2017 to discuss advancing the development of conservation planning tools. In February 2017, the PLC defined its function and purpose and outlined an agenda for teleconferencing and interim due dates for a timeline spanning 2 years (2017-18).

In addition to the members of the committee (table 1.1), participation from other agencies, states, and individuals was necessary to collect and analyze empirical data for this project. These organizations, agencies, and persons are cited as data sources, analysis sources, or outside expert consultants in the "Supplemental Information" and the "Acknowledgments" section.

Table 1.1. Priority Landscapes Committee members and affiliations.

\begin{tabular}{|c|c|}
\hline Name & Affiliation \\
\hline Michael Brasher & DU, Gulf Coast Joint Venture \\
\hline Greg Soulliere & USFWS, Upper Mississippi River and Great Lakes Joint Venture \\
\hline David Howerter & DU Canada, Prairie Habitat Joint Venture \\
\hline Stuart Slattery & DU Canada, Prairie Habitat Joint Venture \\
\hline Mindy Rice & USFWS, National Wildlife Refuge System, Inventory and Monitoring Initiative \\
\hline Joe Fuller & North Carolina Wildlife Resource Commission \\
\hline Josh Vest & USFWS, Intermountain West Joint Venture \\
\hline Sean Fields & USFWS, Prairie Potholes Joint Venture \\
\hline Kathy Fleming & USFWS, Patuxent Wildlife Research Center \\
\hline Luke Naylor & Arkansas Game and Fish Commission \\
\hline
\end{tabular}




\section{Appendix 2. Purpose and Function of Priority Landscapes Committee}

The purpose and function of the Priority Landscapes Committee are show in figure 2.1. Responsibilities are described below. Priority Landscapes Committee (PLC) Function and Work Plan:

It is the responsibility of the PLC to

1. Identify "management guilds" of waterfowl on the basis of life history strategies.

a. Justification: Conservation occurs through habitat delivery; therefore, identifying habitat, spatially, that benefits all waterfowl is unlikely. There are trade-offs among waterfowl grouped by life-history strategies (that is, conservation of one habitat type may benefit a group, such as dabbler ducks, but may do nothing to benefit or may even exclude another group with a different life history strategy). Justifications need to be objective, and "management guilds" need to be based on biological and ecological data.

Exception: Individual spatial layers will be developed for those species that are of high continental priority (that is, based on continental population trend of waterfowl and harvest importance from 2001-15).

2. Identify the appropriate performance measures for each "management guild." Ideally, these will be the same (that is, all groups reported as density maps, abundance maps).

a. Determine the appropriate modelling methods for visualizing "management guilds"/individual species distribution and abundance measures.

3. Collaborate with the Human Dimensions Work Group to identify social objectives.

4. Identify the appropriate performance measures for each social objective.

5. Document the process of developing these conservation planning tools so that it is repeatable and transparent.

6. Provide guidance on the use of developed conservation planning tools.

It is not the charge of the PLC to

1. Assign continental priority values to species.

a. Continental species priorities were revised and published as part of the North American Waterfowl Management Plan (NAWMP, 2004) revision.

2. Set targets (that is, number of ducks or geese for continental populations) for waterfowl species populations at the continental scale (NAWMP, 2012, Appendix A).

3. Assign weights to individual objectives in order to determine the "Priority Geographies for Waterfowl" final map at the continental scale.

\section{References Cited}

North American Waterfowl Management Plan (NAWMP), 2004, North American Waterfowl Management Plan - strengthening the biological foundation (Implementation Framework): U.S. Department of the Interior, Fish and Wildlife Service, and Environment Canada, Canadian Wildlife Service, 120 p.

North American Waterfowl Management Plan (NAWMP), 2012, North American Waterfowl Management Plan 2012-people conserving waterfowl and wetlands: Canadian Wildlife Service, U.S. Fish and Wildlife Service, Secretaria de Medio Amiente y Recursos Naturales, $70 \mathrm{p}$. 


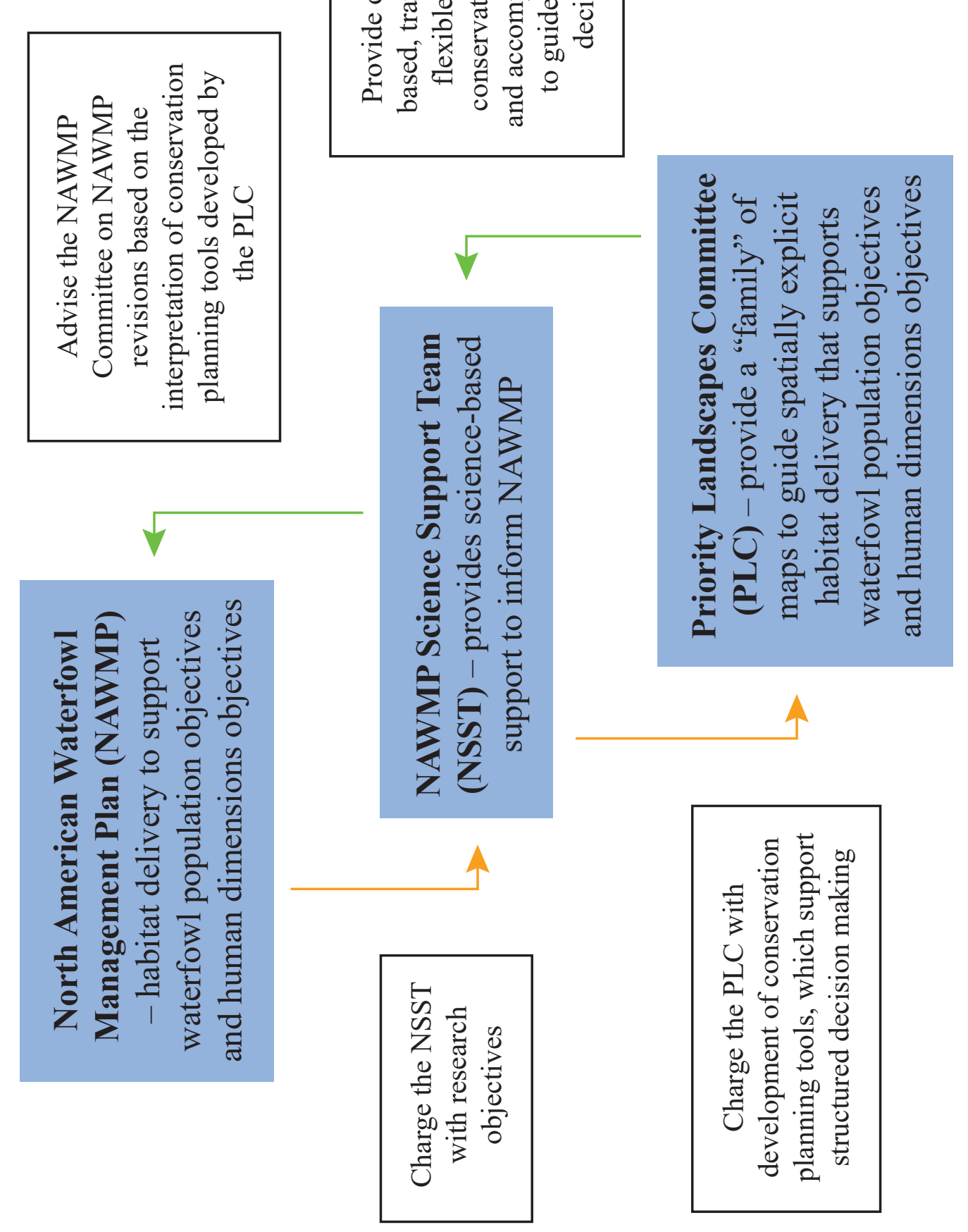




\section{Appendix 3. Means-Ends Network Diagram of Waterfowl Habitat Conservation Decision Context}

The means-ends network diagram (fig. 3.1) was developed by the NAWMP Science Support Team (NSST), the Interim Integration Committee (IIC), and the Priority Landscapes Committee (PLC) in 2015 to guide the framework for integrating the three North American Waterfowl Management Plan (NAWMP) objectives related to waterfowl habitat, waterfowl populations, and human dimensions. The overall goal of NAWMP is in the grey box supported by three fundamental objectives in green boxes. Every other box below these three objectives can be considered a means objective, a way to achieve the fundamental objectives (Gregory and others, 2012). In other words, we are asking "what" do we want to accomplish (in green) and "how" do we get there (the rest of the colored boxes). The PLC recognized that there are various ways in which the fundamental objectives are affected by means objectives. In this case, there are public relations, education, and outreach objectives in pink, the policy and regulation focused objectives in blue, research and academia related objectives in purple, and the objectives that rely on resource allocation at different scales dependent on regional needs in yellow.

\section{Reference Cited}

Gregory, R., Failing, L., Harstone, M., Long, G., McDaniels, T., and Ohlson, D., 2012, Structured decision making: a practical guide to environmental management choices (1st ed.): West Sussex, UK, Wiley-Blackwell, 312 p. 


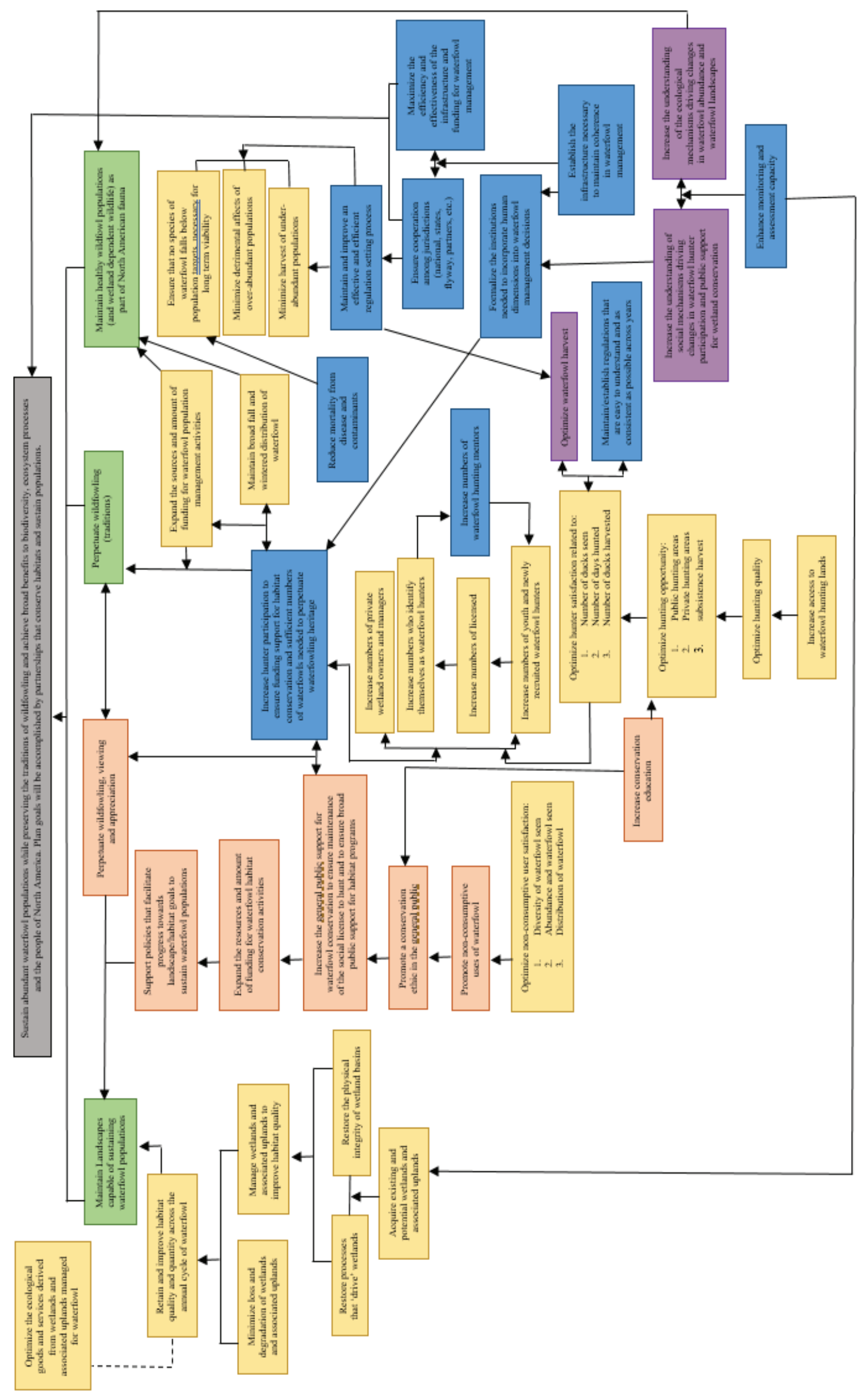

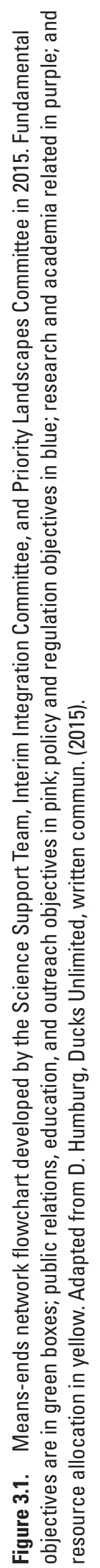




\section{Appendix 4. Biological Objectives: Duck Species Objectives Hierarchy}

"Species prioritization at continental and regional scales has been the subject of considerable attention and vigorous debate. Although lists of priority species have limited potential to directly inform local decisions about where and how to manage habitats, prioritization may provide useful programmatic guidance at regional and continental scales" (North American Waterfowl Management Plan [NAWMP], 2004).

The prioritization of waterfowl species is at its core a subjective process. The NAWMP Science Support Team met in Bismarck, North Dakota, in 2001, to develop a transparent and repeatable methodology for the continental and regional prioritization of waterfowl species, the results of which appear in the 2004 NAWMP. The prioritization methodology was based on two factors - population trend or vulnerability to population decline and socio-economic importance (NAWMP, 2004, see Appendix B for full methodology).

The Priorities Landscapes Committee (PLC) used this prioritization as the benchmark for grouping duck species according to management guilds that are based on feeding and nesting strategy, while acknowledging that some species warrant greater attention and thus should stand alone. These individual species were termed "focal species" owing to special concern for biological or economic (recreational value) issues. These species also typically have a long history of conservation and repeatable, transparent population abundance records accepted by the waterfowl community. Management guilds were based on the feeding and nesting strategy of species. These waterfowl species are generally managed under a larger umbrella of the cohort they fall into. For example, habitat management for Spatula discors (blue-winged teal) usually benefits other species, such as Spatula clypeata (northern shoveler) and Mareca strepera (gadwall), because they tend to have similar habitat requirements during the breeding and non-breeding periods. Additionally, the PLC felt that subspecies distinctions were generally not important at the continental scale, and few population estimates at the subspecies level were available for the time frame of interest (2001-15). Moreover, subspecies separation was considered unnecessary for this study of priority landscapes at the continental level.

Several species of ducks were excluded from analysis, including Anas diazi (Mexican duck), Anas wyvilliana (Hawaiian duck), Anas laysanensis (Laysan duck), Cairina moschata (Muscovy duck), Dendrocygna spp. (whistling duck), Nomonyx dominicus (masked duck), and Histrionicus histrionicus (harlequin duck). Most were excluded because they occur on the Hawaiian Islands and will not effectively identify important areas in continental North America. Others were not systematically surveyed during the breeding season. Finally, a few of these species are permanent residents of Mexico and South America and therefore were not systematically surveyed by breeding waterfowl surveys in North America.

Species population objectives (table 4.1) were published in the NAWMP 2012 revision. Population objectives serve three primary purposes in conservation planning - (1) provide a biological target and plan foundation, (2) function as a performance measure for assessing conservation accomplishments, and (3) operate as a communication and marketing tool to demonstrate the need for conservation (NAWMP, 2012). For a full description of methodology and further detail on continental population targets see Appendix A, NAWMP (2012).

\section{References Cited}

North American Waterfowl Management Plan (NAWMP), 2004, North American Waterfowl Management Plan—strengthening the biological foundation (Implementation Framework): U.S. Department of Interior, Fish and Wildlife Service, and Environment Canada, Canadian Wildlife Service, 120 p.

North American Waterfowl Management Plan (NAWMP), 2012, North American Waterfowl Management Plan 2012-people conserving waterfowl and wetlands: Canadian Wildlife Service, U.S. Fish and Wildlife Service, Secretaria de Medio Amiente y Recursos Naturales, $70 \mathrm{p}$. 
Table 4.1. Biological objectives hierarchy for duck species during the breeding and non-breeding periods.

[Table includes continental-scale population abundance estimates from North American Waterfowl Management Plan (NAWMP), 2012]

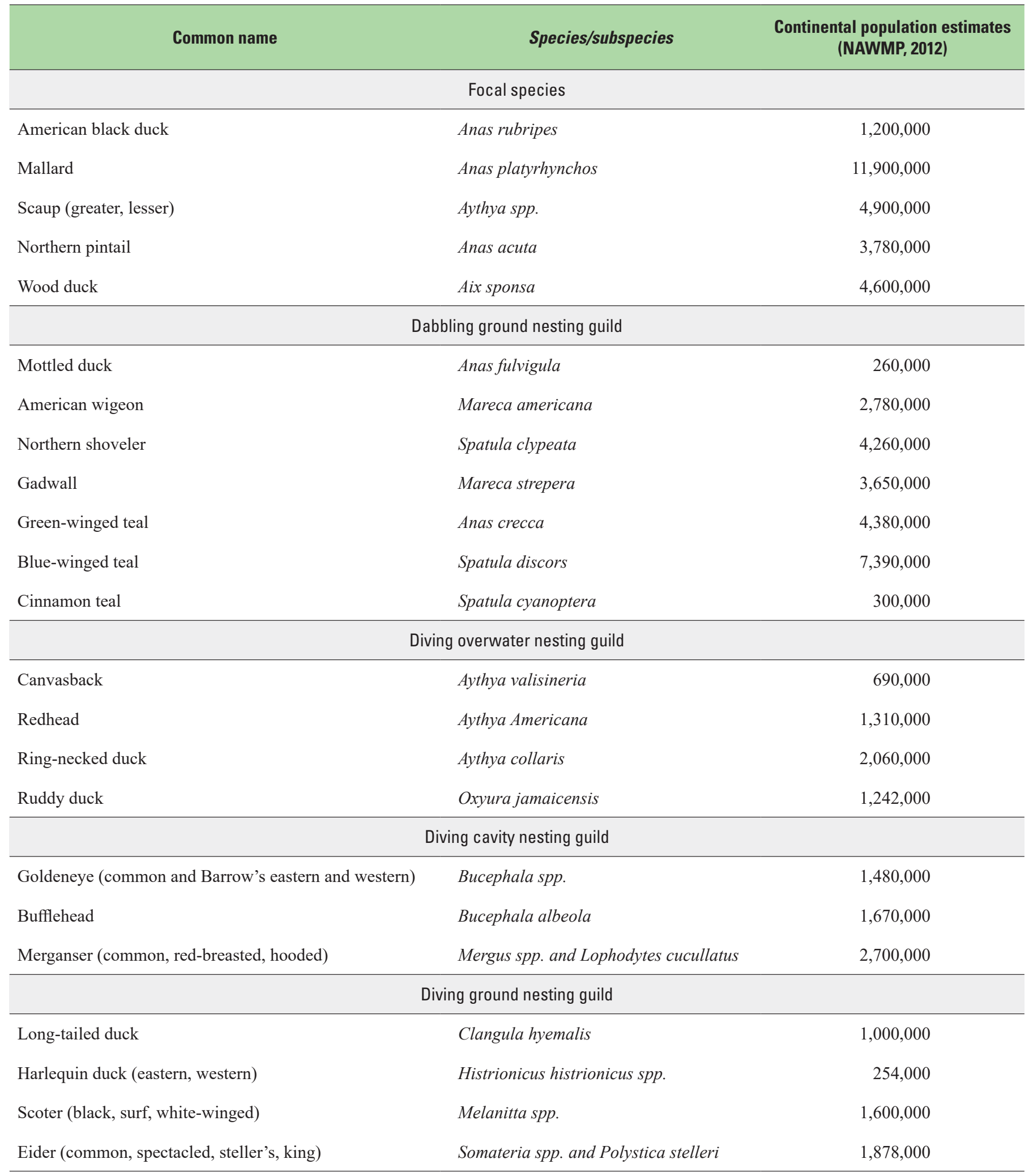




\section{Appendix 5. Biological Objectives: Goose and Swan Species Objectives Hierarchy}

Geese and swans were considered separately from duck species. The Priority Landscapes Committee (PLC) reasoned that, although some goose species (that is, Branta bernicla subspp. [brant] and Anser canagicus [emperor goose]) deserve special attention at the species level, the numbers of most species of swans and geese are above the North American Waterfowl Management Plan (NAWMP) 2012 population objectives (table 5.1), and habitat management in the breeding and non-breeding ranges for these species will not greatly affect nest success and survival. Overabundant geese are a growing concern for waterfowl managers, in part, because they compete with ducks for resources at some locations. However, not including geese or swans in our set of biological objectives would limit the product's ability to identify areas important to all species of waterfowl. Areas of special concern need to be considered, such as in the high Arctic (that is, Banks Island, Victoria Island) and Hudson and James Bays, where geographies are consistently very important to a few breeding goose and swan species. Additionally, goose harvest is an important economic activity for many states and provinces. Therefore, excluding geese and swans from the biological objectives would ignore the importance of geographies that are critical for supporting goose harvest activities. For these reasons, the PLC reasoned that creating a biological objectives hierarchy for geese and swans separately from ducks was warranted.

Our objective was to identify geographies of greatest continental importance for breeding, migrating, and non-breeding geese and swans. The wealth of data that was available for estimating most duck populations was not available for geese and swans. Although several regional breeding surveys were conducted in Alaska and the high Arctic, these efforts are not conducted every year and are not consistent across the continent.

\section{Reference Cited}

North American Waterfowl Management Plan (NAWMP), 2012, North American Waterfowl Management Plan 2012-people conserving waterfowl and wetlands: Canadian Wildlife Service, U.S. Fish and Wildlife Service, Secretaria de Medio Amiente y Recursos Naturales, $70 \mathrm{p}$.

Table 5.1. Biological objectives hierarchy for goose and swan species during the breeding and non-breeding periods.

[Table includes continental-scale population abundance estimates from North American Waterfowl Management Plan (NAWMP), 2012. NA, not applicable]

\begin{tabular}{llc}
\multicolumn{1}{c}{ Common name } & Species/subspecies & $\begin{array}{c}\text { Continental population estimates } \\
\text { (NAWMP, 2012) }\end{array}$ \\
\hline Canada and cackling goose* & Branta canadensis & $3,684,100^{\mathrm{a}}$ \\
Snow goose & Anser caerulescens & $2,430,000^{\mathrm{a}}$ \\
Ross's goose & Anser rossii & $100,000^{\mathrm{a}}$ \\
White-fronted goose & Anser albifrons & $910,000^{\mathrm{a}}$ \\
Emperor goose & Anser canagicus & $150,000^{\mathrm{b}}$ \\
Brant & Branta bernicla & $312,000^{\mathrm{b}}$ \\
Tundra swan & Cygnus columbianus & $140,000^{\mathrm{a}}$ \\
Trumpeter swan & Cygnus buccinator & $27,000^{\mathrm{a}}$ \\
Mute swan & Cygnus olor & $\mathrm{NA}^{\mathrm{c}}$ \\
\hline
\end{tabular}

"Cackling goose was not distinguished from Canada goose because there were limited data on the distribution and range of cackling goose.

aContinental population estimate (2002-11; NAWMP 2012) is above the population target.

${ }^{b}$ Continental population estimate (2002-11; NAWMP 2012) is below the population target.

${ }^{\mathrm{c}}$ Mute swan does not have a continental population target because it is non-indigenous species of swan. 


\section{Appendix 6. Social Objectives Hierarchy}

On the basis of the preliminary results of the Human Dimensions Working Group, the Priority Landscapes Committee (PLC) discussed the importance of resource allocation to waterfowl habitat conservation initiatives in providing benefits to multiple resource user groups. Three waterfowl habitat conservation supporter groups were identified: waterfowl hunters, bird watchers, and landowners and the general public. North American Waterfowl Management Plan (2012) identifies a need for integration of biological objectives with the social objectives that retain, recruit, and reactivate waterfowl habitat conservation supporters (fig. 6.1). Therefore, the PLC focused on social objectives that theoretically increase waterfowl hunter and bird watcher satisfaction, and that provide ecosystem goods and services which potentially garner public support for waterfowl habitat conservation. Several assumptions were outlined.

Assumptions:

- Habitat delivery (that is, acquisition, enhancement, restoration, management) in areas where the waterfowl hunting community is most active (highest values for hunter days afield) will result in increased recruitment, retention, and reactivation of hunters by decreasing crowding, increasing access (to some extent), and increasing the total amount of huntable land. The presence of an active hunting community is assumed to be important for new hunter recruitment owing to rule complexity and equipment needs.

- Habitat delivery closer to population centers will increase recruitment, retention, and reactivation of hunters by decreasing crowding, increasing access (to some extent), increasing the total amount of huntable land, and increasing support for habitat conservation (similar assumption for bird watchers).

- Habitat delivery in areas with a greater wetland species diversity index will increase recruitment, retention, and reactivation of bird watchers.

- Habitat delivery in areas where obligate wetland bird diversity is high will increase bird watcher satisfaction and support for waterfowl habitat conservation.

- Habitat delivery in areas where watersheds are most degraded (greatest coverage by agriculture and urban development) will increase ecosystem function and resilience, improving water quality, flood abatement, drought mitigation, carbon sequestration capabilities, total acreage of green space for recreation, and aquifer recharge, thus increasing public support.

\section{Reference Cited}

North American Waterfowl Management Plan (NAWMP), 2012, North American Waterfowl Management Plan 2012-people conserving waterfowl and wetlands: Canadian Wildlife Service, U.S. Fish and Wildlife Service, Secretaria de Medio Amiente y Recursos Naturales, $70 \mathrm{p}$. 


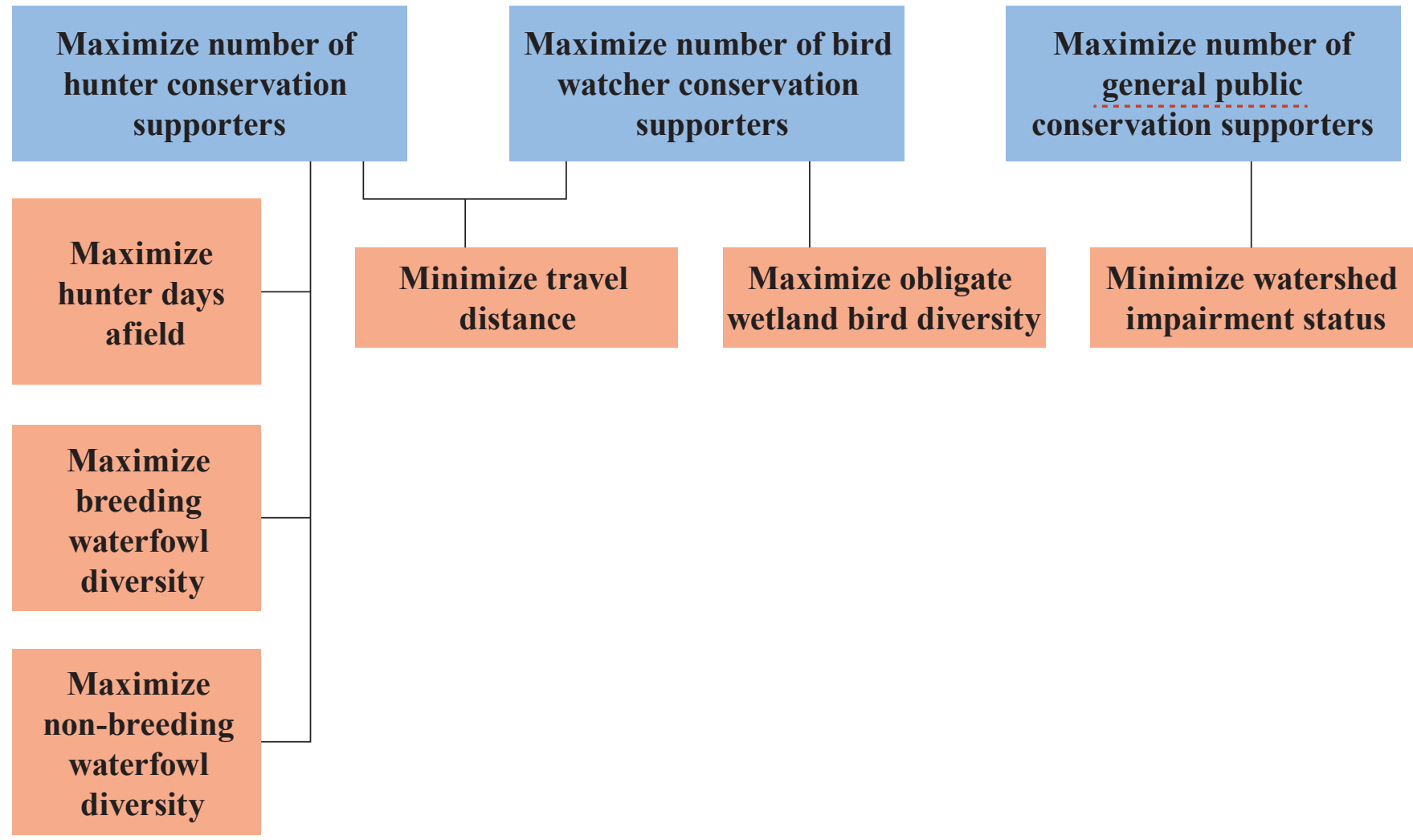

Figure 6.1. Social Objectives Hierarchy. Blue boxes are fundamental objectives; orange boxes are sub-objectives. 
For additional information, contact:

Director, Patuxent Wildlife Research Center U.S. Geological Survey

12100 Beech Forest Road, Ste 4039

Laurel, MD 20708-4039

Or visit our website at: http://www.pwrc.usgs.gov/

Publishing support provided by the West Trenton Publishing Service Center 


\section{量}

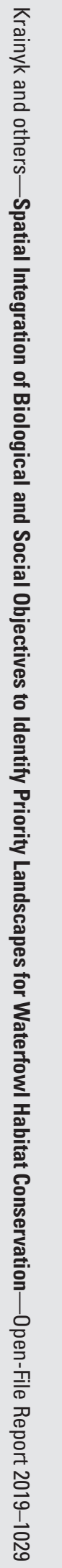

